\title{
PROPOSTA DE ESPORTE, LAZER E TURISMO NÁUTICO NA BACIA E NA ORLA DO LAGO PARANOÁ - BRASÍLIA/DF
}

\author{
Aluna: Maria de Jesus Pontes \\ Orientadora: Prof ${ }^{\mathrm{a}}$. Dr ${ }^{\mathrm{a}}$. Cléria Botelho Costa \\ Monografia apresentada ao Centro de \\ Excelência em Turismo da \\ Universidade de Brasília como \\ requisito parcial para a obtenção do \\ certificado de Especialista em \\ Turismo e Hospitalidade
}


UNIVERSIDADE DE BRASÍLIA

Centro de Excelência em Turismo

Curso de Especialização para Professores e Pesquisadores em Turismo e

Hospitalidade

\section{PROPOSTA DE ESPORTE, LAZER E TURISMO NÁUTICO NA BACIA E NA ORLA DO LAGO PARANOÁ - BRASÍLIA/DF}

Maria de Jesus Pontes

Banca Examinadora

Prof ${ }^{\text {a }}$ Cléria Botelho Costa, Doutora

Orientadora

Professor

Membro da Banca

Brasília, DF, dezembro, 2003 
MARIA DE JESUS PONTES

\section{PROPOSTA DE ESPORTE, LAZER E TURISMO NÁUTICO NA BACIA E NA ORLA DO LAGO PARANOÁ - BRASÍLIA/DF}

Comissão Avaliadora

Prof $^{\text {a }}$. Cléria Botelho Costa

Professora e Orientadora

Professor

Brasília, DF, dezembro, 2003 
Dedico este trabalho ao meu pai José Ferreira Pontes à minha mãe Maria Araci Pontes (in memorian) ao meu filho Thiago Izaias Pontes, que neles reside toda fonte de inspiração para minha vida 


\section{AGRADECIMENTO}

A Deus, o Criador dos Céus e da terra, natureza (mar, sol, lua estrelas), animais e todos os seres viventes, razão da minha existência

Ao Centro de Excelência em Turismo - CET da Universidade de Brasília - UNB,

pelo crescimento na área profissional, gerando novos conhecimentos trazendo êxito no trabalho.

Aos meus familiares com quem dividimos nossas alegrias e os frutos do nosso trabalho.

À Coordenadora do Curso de Especialização para Professores $\operatorname{Dr}^{\mathrm{a}}$ Tânia Siqueira Montoro, pela dedicação ao ensino e estímulo para o crescimento profissional.

Aos professores, em especial à Dr ${ }^{\mathrm{a}}$ Cléria Botelho Costa, à Prof ${ }^{\mathrm{a}}$. Sandra Von Tiesenhausen e à Dra Maria Thereza Negrão de Melo pela amizade e ensinamentos.

À colega Amélia que foi incansável na troca de experiência sobre o trabalho.

À J.R. Martins pela revisão lingüística dos textos.

À Mariana Lima e Sá, Fernando Souza Soares e Ivana Lasse Said de Abreu, que me auxiliaram na digitação de textos, tabelas, quadros e mapas.

Aos amigos Elzenir da Silva Portela , Érika da Silva Portela e João Bosco Portela, que colaboraram na pesquisa, leitura dos textos e montagem da monografia.

Aos senhores Marcos Pompeu de Souza Brasil e Evander Wilson Marques pela acolhida para a entrevista.

À todos que, direta ou indiretamente, participaram da edição desta monografia. 


\section{EPÍGRAFE}

“...Quisera Deus, acordar cedo, preparar o barco e a rede para contemplar a escala bucólica do Lago Paranoá. Encantar-se com a natureza, é encantar-se com Deus que presenteou o homem para amá-la..."

(Maria de Jesus Pontes) 


\section{RESUMO}

Os instrumentos de gestão do Lago Paranoá, turismo náutico, esporte e lazer, discutidos neste trabalho, constituem uma contribuição para o desenvolvimento do turismo no Distrito Federal. O manejo, inclusive à integração de aspectos relacionados ao solo, à água, e a paisagem, chamam para si a promoção de uma abordagem dinâmica, interativa e multissetorial do Lago Paranoá, incluindo a identificação e proteção de fontes importantes para o desenvolvimento sócio-econômico, ambiental e cultural, pois a bacia hidrográfica precisa ser reconhecida como unidade de gestão dos recursos hídricos. É nela que ocorre interações complexas de inúmeros processos físicos, que exigem esforços para análise de maneira adequada e ampla para efeito rápido dos projetos advindos para fomentar o turismo na orla do Lago Paranoá.

Palavras-chave: Lago Paranoá, Turismo Náutico, Esporte. 


\begin{abstract}
The instruments of management of the Paranoá Lake, nautical tourism, sport and leisure, argued in this work, constitute a contribution for the development of the tourism in the Federal Distrito. The handling, also to the integration of aspects related to the ground, the water and the landscape, calls for itself the promotion a dynamic, interactive and multissetorial boarding of the Paranoá Lake, including identification protection of important sources for the development economic, ambient and cultural partner, therefore the necessary hydrographic basin to be recognized as unit of management of the hidricos resources. It is in that it occurs complex interactions of innumerable physics processes that demand efforts for analysis in adequate and ample way for fast effect; them happened projects to foment the tourism in the edge of the Paranoá Lake.
\end{abstract}

Key-words: Paranoá Lake, Nautical Tourism, Sport 


\section{SUMÁRIO}

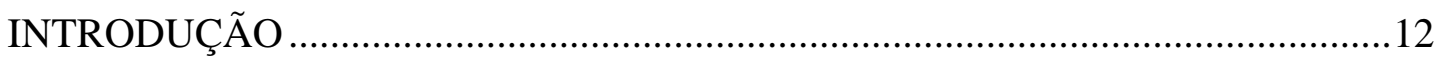

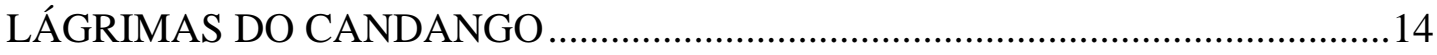

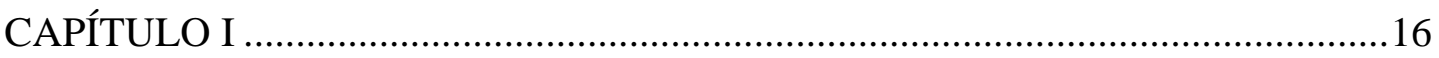

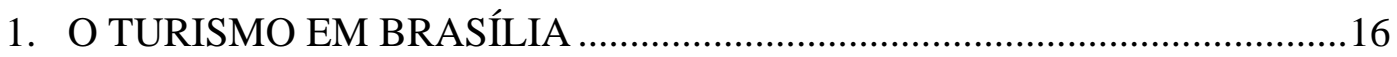

2. HISTÓRICO DA HOTELARIA EM BRASÍLIA …........................................16

3. BRASÍLIA - CENÁRIO IDEAL PARA GRANDES INICIATIVAS

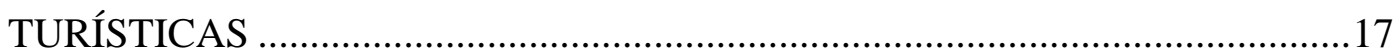

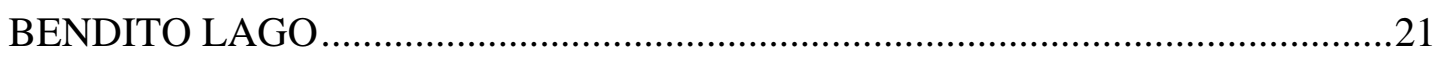

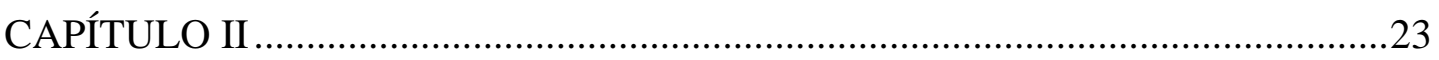

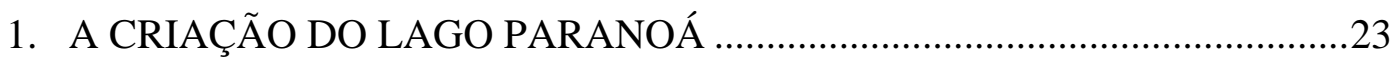

2. OS PROJETOS PARA A NOVA CAPITAL ..................................................23

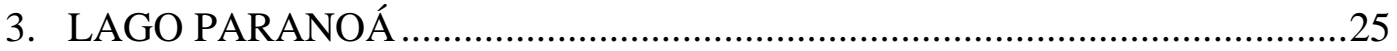

3.1. A Obra da Barragem .............................................................................27

3.2. Bacia do Lago Paranoá ...........................................................................35

3.2.1. Ribeirão do Torto..........................................................................37

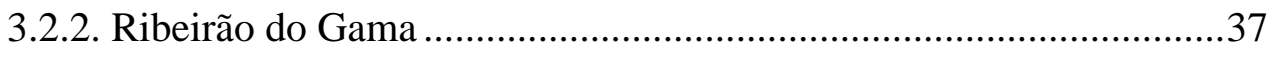

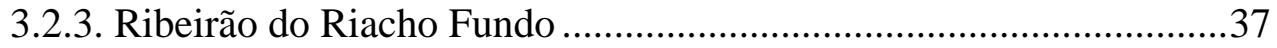

3.2.4. Ribeirão do Bananal...........................................................................37

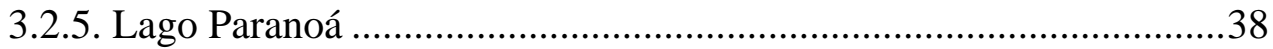

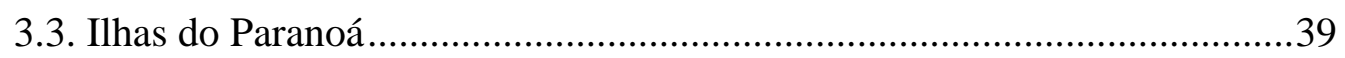

3.3.1. Ilha do Paranoá ............................................................................39

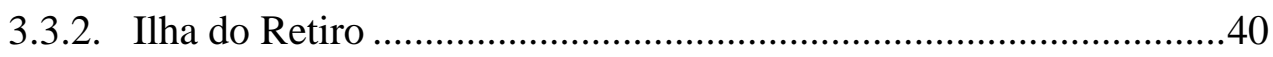

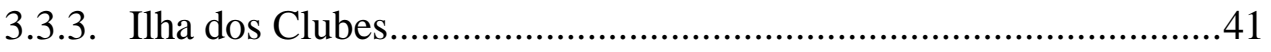

BRASÍLIA CONGREGANDO DIFERENTES CONTRIBUIÇÕES

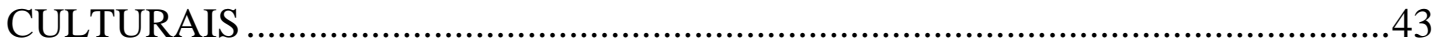

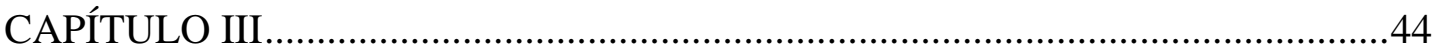

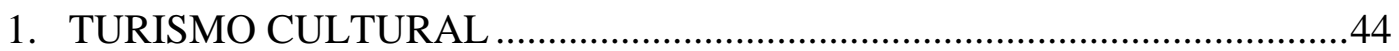

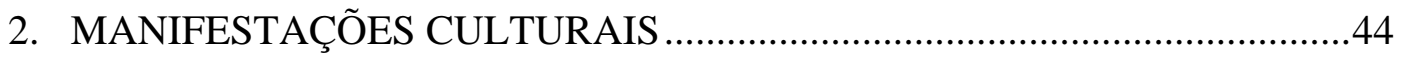

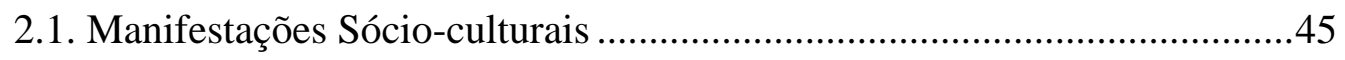

2.2. Manifestações Esportivas .......................................................................46

2.3. Manifestações Econômicas......................................................................46 
3. BENS DE VALOR HISTÓRICO CULTURAIS .........................................46

3.1. A terceira Ponte do Lago Sul ............................................................47

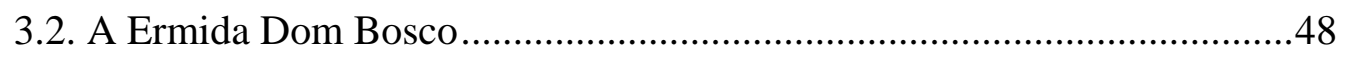

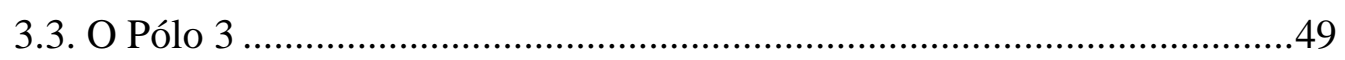

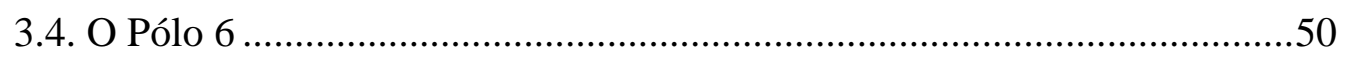

3.5. O Pontão do Lago Sul ............................................................................51

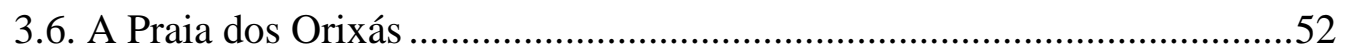

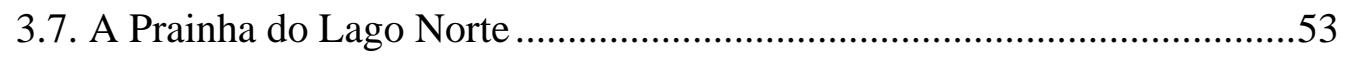

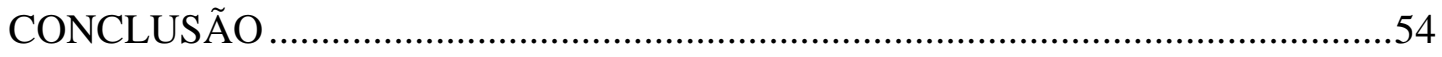

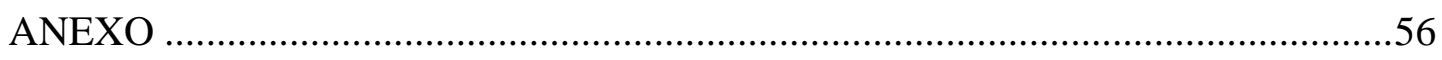

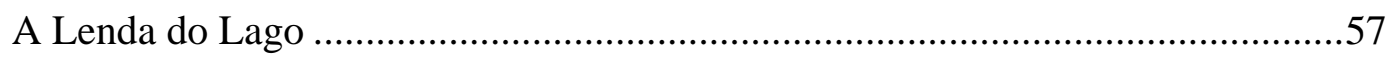

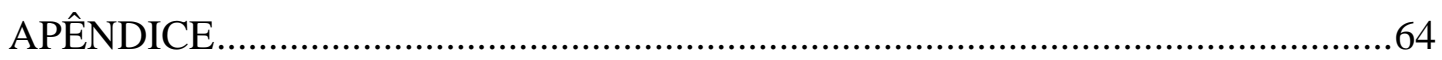

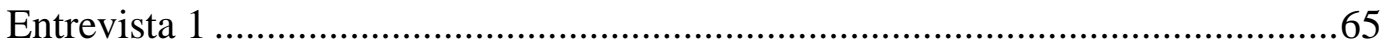

Entrevista 1 - Marcos Pompeu ......................................................................66

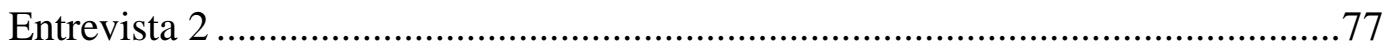

Entrevista 2 - Evander Marques ................................................................. 78

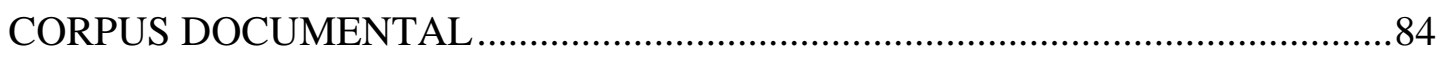

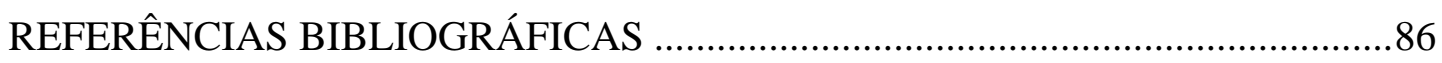




\section{LISTA DE ILUSTRAÇÕES}

Tabela 1- Lago Paranoá, Características Gerais

Figura 1 - Pôr do Sol no Lago Paranoá

Figura 2 - Bacia do Lago Paranoá, Carta de Drenagem............................................ 36

Figura 3 - Turismo Náutico no Lago Paranoá.......................................................... 43

Figura 4 - A Terceira Ponte do Lago Sul .......................................................... 47 


\begin{tabular}{ll}
\hline & Abreviatura \\
\hline AABB & Associação Atlética Banco do Brasil \\
\hline ABAVE & Associação Brasileira das Agências de Viagem \\
CET & Centro de Excelência em Turismo \\
cm & Centímetros \\
DF & Distrito Federal \\
Ed. & Editora \\
EIA & Estudos de Impacto Ambiental \\
EMBRATUR & Instituto Brasileiro de Turismo \\
GDF & Governo do Distrito Federal \\
IBPC & Instituto Brasileiro de Patrimônio Cultural \\
Km & Quilômetro \\
Km & \\
M & Quilômetro quadrado \\
M & Metros \\
ML & Metros cúbicos \\
No & Mansões do Lago \\
NOVACAP & Número \\
OMT & Companhia Urbanizadora da Nova Capital \\
p. & Organização Mundial do Turismo \\
PIB & Página \\
PRODETUR & Produto Interno Bruto \\
S & Programa de Desenvolvimento Turístico \\
SEBRAE & Segundo \\
SEMARH & Serviço Brasileiro de Apoio às Micro e Pequenas Empresas \\
SENAC & Secretaria de Meio Ambiente e Recursos hídricos \\
QL & Serviço Nacional de Aprendizagem Comercial \\
SETUR & Quadras do Lago \\
UNB & Secretaria de Turismo do Distrito Federal \\
UNESCO & Universidade de Brasília \\
& Organização das Nações Unidas para a Educação, Ciência e Cultura \\
& \\
\hline
\end{tabular}




\section{INTRODUÇÃO}

Durante a fase da escolha do tema para esta monografia, muitas foram as informações consultadas; todas relacionadas às possibilidades de desenvolvimento do turismo no Distrito Federal e no seu Entorno. Dessas consultas, porém as que mais se afiguraram atraentes foram aquelas que dizem respeito às belezas e encantamentos que, em nossa região, o Lago Paranoá, tem a oferecer a todos que o sabe ver e admirar, além de suas potencialidades turísticas. Isso fez que nossa escolha, mais e mais se inclinasse pelo tema Turismo Náutico.

Mas não foi só, o estudo consultado sobre o Lago Paranoá, mostra suas potencialidades para o esporte e o lazer; tudo dentro de um cenário propício ao turismo náutico, tudo dentro de uma paisagem harmoniosa e contemplativa, capaz de surpreender e de provocar a simpatia de todos que o visitam.

Outros fatores que se fizeram relevantes na escolha do tema são: mostrar que Brasília, como pólo turístico, não oferece a seus visitantes apenas palácios e prédios públicos, não só os grandes e diversificados shoppings, o que a tornaria uma cidade fria como muitos a consideram, mas uma cidade com amplas potencialidades para o desenvolvimento do turismo.

Mostrar as amplas possibilidades que Brasília possui para oferecer aconchego e calor humano a seus turistas, mediante a implementação, especialmente do "Projeto Orla" que visa dotar as margens do Lago Paranoá dos equipamentos indispensáveis a que nossos visitantes possam desfrutar de diversificadas modalidades do esporte, de lazer, de divertimento, tudo em meio às suas belezas naturais e a um sadio convívio humano.

Para complementar o "Projeto Orla” visa dotar o Lago Paranoá de outros produtos/serviços que possam ampliar e qualificar, ainda mais o atendimento de nossa população e dos nossos visitantes, nas áreas de lazer e de cultura. Uma sugestão para essa ampliação seria a operação de uma “chata”, com capacidade para um mínimo de 300 pessoas, devidamente preparada e equipada para festas, para alimentação e apresentação culturais. Além dessa,outras idéias ocorre-nos e, dentre elas, uma, seria a construção de um museu de história natural. 
Diante do que acima expusemos, não foi difícil decidirmos pelo tema a que mencionamos: “Turismo Náutico”. A partir daí, bastou-nos correr atrás de dados e fontes de informações para a realização deste trabalho, dividida em três capítulos com os títulos: “O Turismo em Brasília”, “O Lago Paranoá” e o “Turismo Cultural”.

No primeiro capítulo fizemos um comentário panorâmico do turismo em Brasília e no Distrito Federal, onde enfocamos, inclusive aspectos históricos do turismo na Capital da República. Sob o segundo, o nosso enfoque é a Lago Paranoá e suas potencialidades de desenvolvimento, além daquilo que já existe. Finalmente, sob o último título, focalizamos os aspectos culturais dos produtos/serviços existentes e daqueles possíveis de serem empreendimentos, no presente e no futuro 


\section{LÁGRIMA DE CANDANGO}

Não fique triste Candango,

Feche estes olhos molhados

E pare de recordar.

Não há mais acampamento,

Tudo aqui é monumento,

Você não pode ficar.

Tire os Olhos da Avenida,

Despeje o pranto no Lago.

Não fique olhando o Palácio,

O prédio que você fez

E agora não pode entrar.

Não fique triste Candango

Tire os olhos do passado

E ponha-os na imensidão.

Bata na porta do Céu,

Acampe na Eternidade...

Fique bastante à vontade,

Lá você pode morar...

O seu choro vira chuva,

Vira luz o seu olhar. 
E de lá... olhe cá embaixo...

É tão pequeno este mundo!

Não vale a pena chorar.

(Newton Rossi) 


\section{CAPÍTULO I}

\section{O TURISMO EM BRASÍLIA}

O turismo em Brasília, teve início, ainda, nos tempos de sua construção, no período de 1956 a 1960. Naquela época os visitantes se hospedavam precariamente em hotéis de madeira localizados na então Cidade Livre, hoje, Núcleo Bandeirante. Eram pessoas curiosas, vindas das mais diversas regiões do país para ver de perto o andamento das obras da construção da nova capital, muitos dos quais resolveram somar esforços com aqueles que aqui já se encontravam.(Segundo J.R. Martins - Pioneiro de Brasíla-DF.)

\section{HISTÓRICO DA HOTELARIA EM BRASÍLIA}

Inaugurado o Brasília Palace Hotel, às margens do Lago Paranoá e próximo ao Palácio da Alvorada, foi este o primeiro hotel a entrar em funcionamento, antes mesmo da inauguração de Brasília, tendo sido o único hotel construído em alvenaria a oferecer relativas acomodações às autoridades e visitantes ilustres até que em 21 de abril de 1961, foi inaugurado o Hotel Nacional, com todos os serviços que correspondia à hotelaria moderna daquela época.

Em pouco tempo as acomodações oferecidas pelos hotéis mencionados, tornaram-se insuficientes para hospedagem de tantos que aqui aportavam em viagens de interesses políticos, culturais e negócios. Isso estimulou empresários estabelecidos em outras cidades a virem construir novos hotéis na cidade dando assim, início a expansão da rede hoteleira de Brasília.

Vale lembrar que o turismo em Brasília nos seus primeiros anos esteve prejudicado por muitos anos em vista da falta de infra-estrutura em termos de transportes e meios de comunicação. Além dos palácios governamentais e da arquitetura arrojada da cidade, os únicos atrativos resumiam-se à televisão, às poucas emissoras de rádio, ao cinema, à festa dos estados com apresentação de conjuntos folclóricos, culinária e produtos artesanais. A 
carência de serviços de saúde, também contribuiu para dificultar ainda mais o desenvolvimento do turismo em Brasília. .(Segundo J.R. Martins - Pioneiro de BrasíliaDF.)

\section{BRASÍLIA - CENÁRIO IDEAL PARA GRANDES INICIATIVAS TURÍSTICAS}

Ao completar 39 anos de fundação, Brasília através do Governo do Distrito Federal, toma iniciativa concreta para transformar-la em capital brasileira de turismo. A Secretaria de Turismo e Lazer do GDF criou uma oficina de planejamento e estratégia para o desenvolvimento do setor. Logo que assumiu a pasta, o secretário Lourival Zagonel deixou claro, no seu discurso de posse, que a filosofia da SETUR - Secretaria do Turismo do Distrito Federal era elaborar um plano diretor de turismo articulado com a iniciativa privada, principalmente com o trade turístico.

Tratada sempre como cidade da burocracia, em função da sede dos poderes executivo, legislativo e judiciário, Brasília, embora com um conjunto arquitetônico que foi reconhecido como patrimônio cultural da humanidade pela UNESCO, nunca teve, na prática, um projeto que encarasse o turismo como atividade fundamental no seu desenvolvimento.

No período de 26 a 28 de fevereiro de 1999, com a presença de representantes da EMBRATUR - Instituto Brasileiro de Turismo, Brasília Covention \& Bureau, Universidade de Brasília e todos os órgãos do Governo do Distrito Federal e trade turístico, foram identificadas as potencialidades turísticas do DF e traçadas metas para o seu desenvolvimento. $\mathrm{O}$ encontro entre governo e iniciativa privada permitiu que a Secretaria de Turismo e Lazer ouvisse os anseios e expectativas da comunidade ligada direta e indiretamente ao turismo, possibilitando maior diálogo e dinamicidade para as ações futuras.

Outra parceria de total importância foi a do governador Joaquim Roriz com todos os embaixadores da América Latina e Caribe, visando uma política de intercâmbio turístico entre as capitais. Com a vinda de grandes capitais internacionais para investimentos nos setores de hotelaria, parques temáticos, entre outros segmentos do turismo. 
Brasília tem todas as condições para se tornar um grande pólo turístico nacional e internacional. A cidade está inserida no coração político do Brasil, reunindo consideráveis equipamentos, hoje, capazes de responder por um eficiente atendimento a brasileiros e estrangeiros que optam por conhecer a capital da república, a exemplo do que acontecem em tantas outras cidades, do mundo, donas do mesmo status.

Brasília é bastante requisitada para a realização de eventos profissionais e encontros políticos. congressos, seminários, fóruns, encontros de toda natureza fazem de Brasília a Capital do debate. Sede dos poderes da República, a cidade é palco ideal para quem precisa dar repercussão às suas idéias e propostas, podendo contar com a presença de qualquer autoridade do governo.

O que está visível é que Brasília carece de iniciativas públicas e privadas, para alçar o vôo que suas potencialidades recomendam.

Foi por acreditar nessas potencialidades que, há seis anos, o IBPC patrocina estudos destinados a traçar de maneira detalhada, por meio de pesquisa científica, o Perfil do Turismo no Distrito Federal. Uma iniciativa da maior relevância, pois é a forma de pavimentar o caminho para que a cidade siga sua vocação. No contato direto com mais de 3.500 turistas, o referido órgão, durante a pesquisa de campo, reconheceu a necessidade premente de divulgar o produto “Brasília” junto ao mercado consumidor em potencial.

Nada é mais importante, nesse particular, do que o respaldo de dados científicos para adotar-se mecanismos capazes de ensejar o aumento da média de permanência dos que visitam a cidade, ou atender às expectativas relevadas pela pesquisa, no que concerne à oferta de produtos turísticos e alternativos de programas de lazer e entretenimento aos visitantes de Brasília.

Aliás, essa é a tendência do mundo, especialmente das cidades com idêntico potencial turístico; formatar um produto original, criativo, interessante, para atrair o turista, seja por iniciativa própria ou estimulado por amigos ou outros meios de comunicação. O que emerge da pesquisa é a necessidade de deixar o turista com a liberdade de escolhas, de acordo com suas convivências culturais, o lugar ou os lugares que ele deseja conhecer.

Para a definição do perfil do Turista no Distrito Federal, a referida pesquisa evidenciou a necessidade de divulgação do produto "Brasília” como efetiva opção turística, por trata-se da Capital Federal, com monumentos e prédios públicos abertos a visitação, pela sua arquitetura capaz de despertar o interesse de milhares de profissionais e estudantes 
dessa área em todo o mundo, para conhecer a obra de Oscar Niemeyer, ou os aspectos místicos da cidade, outra potencialidade conferida bem assim, por sua condição de uma das poucas cidades modernas do mundo, inscrita como Patrimônio Cultural da Humanidade.

Os índices de desenvolvimento de Brasília são elevados. Nada demais para uma cidade que registra a presença de $80 \%$ do funcionalismo público federal, com salários estáveis, o que significa uma injeção mensal de recursos substanciais em sua economia, não obstante estarem estes, a mais de 7 anos, sem nenhum reajuste.

Quanto ao potencial do mercado de viagens, é quase lugar comum repetir que o turismo figura como o terceiro produto da balança comercial brasileira, e que a OMT Organização Mundial do Turismo entende o turismo como o mais rápido caminho para que as populações alcancem o desenvolvimento político-econômico-social, diminuindo as desigualdades e aumentando as oportunidades de emprego e renda, e que o turismo responde por $10 \%$ da força de trabalho no mundo, tendo movimentado US\$ 4,5 trilhões no ano 2000.

O ser humano por sua natureza tem o hábito de consumir, sempre, produtos e serviços, sejam eles pagos ou não. O Brasil é um país capitalista e sua população consome o tempo inteiro, ou seja, 24 horas por dia. Serviços e produtos, nesta ordem, são consumidos diariamente pelas pessoas no mundo inteiro.

Os serviços mais consumidos são alimentação, diversão, energia, água, transporte, hospedagem, telecomunicações entre outros, mais específicos que correspondem as necessidades de cada ser. Os produtos estão subentendidos dentro dos serviços. E falandose dos serviços na área do turismo, podemos relacionar, como produtos, aqueles oferecidos pelas novidades da hotelaria, dos transportes, em toda sua diversidade, bem como os oferecidos, pelas empresas ou instituições relativas à alimentação, ao lazer e a cultura. Assim sendo, para a definição do Perfil do Turista no DF, uma das preocupações é conhecer e avaliar, sob o ponto de vista dos visitantes de Brasília, seus principais hábitos de consumo, de serviços/produtos quando de sua estada nesta cidade. Este item abordará e demonstrará, de forma geral, os resultados alcançados, nos cinco estudos, onde serão destacados os itens que ora para mais e ora para menos, em termos de gastos, surpreenderam os turistas quanto aos preços praticados aqui em Brasília. Brasília é considerada pela maioria da população brasileira, como a capital que oferece serviços e produtos mais caros em comparação com outras cidades/estados do país. Este dado não é questionável, podendo ser verificado nos itens a seguir, onde a média de gastos, até a 
avaliação dos serviços/produtos recebidos pelos turistas serão demonstrados de maneira a permitir uma melhor visualização daquela crença, a fim de orientar e direcionar tomadas de decisões no que tange a política de turismo para a capital.

Dessa forma, Brasília tem tudo para emergir como um destino de excelência, produto sem concorrência no Brasil. 


\section{BENDITO LAGO PARANOÁ}

Bendito Lago que a todos proporciona alegria

Ao iatista, acolhe com águas limpas e tranqüilas,

Quando a cada manhã, ao desportista também propicia,

O necessário revigoramento corporal para formas belas

Bendito Lago que traz doces recordações

Aos piauienses, cearenses amantes de um bravio mar

Que afoga as saudades e faz nascer constantes orações

Quando lembra da terra com constante desejo de voltar

Bendito Lago que lembra um rio do interior

Seja mineiro, goiano, mais ao sul mais ao norte,

Que vem em busca de uma oportunidade melhor

E aqui fica sempre desafiando nova vida, nova sorte;

\section{Pôr do Sol no Lago Paranoá}

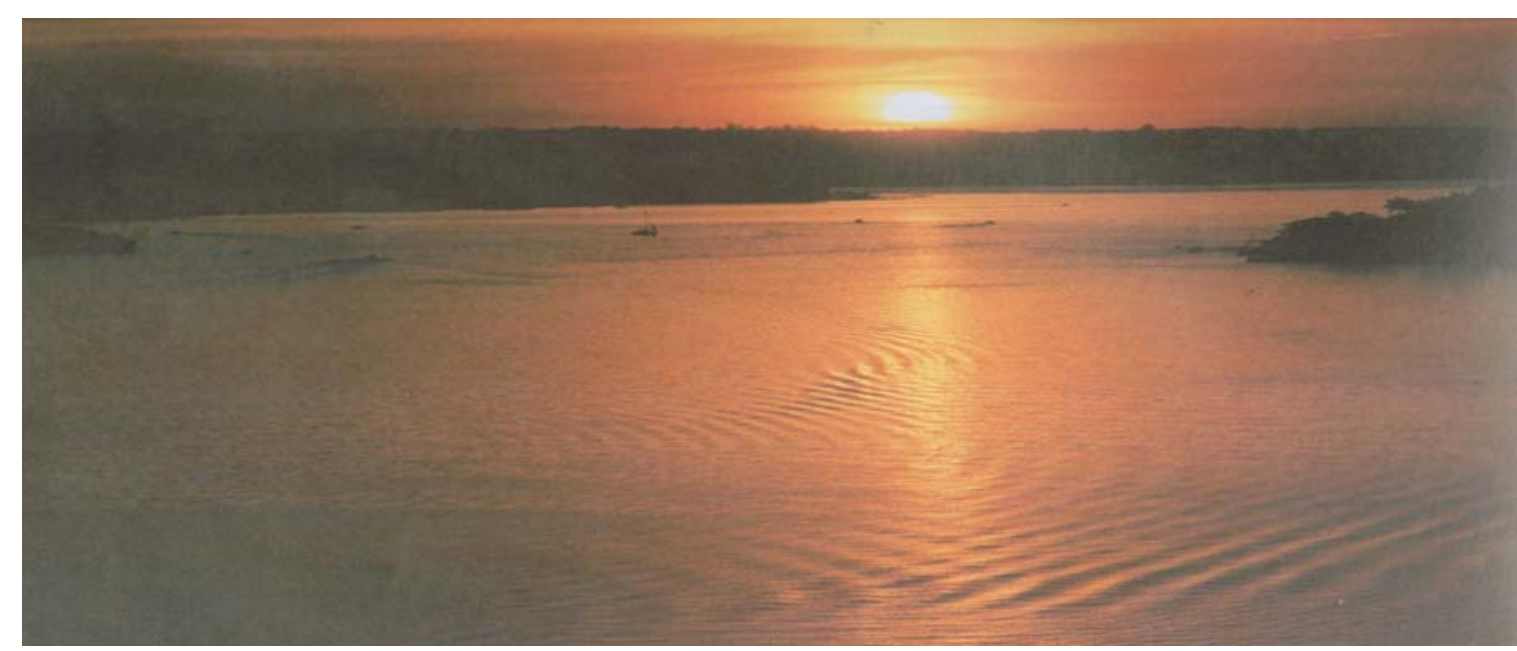

Figura 1 - Olhares sobre o Lago Paranoá, 2003, p. 164 
Bendito seja sempre nosso: Lago Paranoá

Que encanta os de raça, cor e religião.

Envolvendo a todos em místico relacionamento

Exibindo o belo pôr do sol para calar solidão

(Maria de Jesus Pontes e João Bosco Portela) 


\section{CAPÍTULO II}

\section{A CRIAÇÃO DO LAGO PARANOÁ}

Em abril de 1955, o Sítio Castanho foi escolhido para abrigar a nova capital, exatamente no local onde esteve acampada a comitiva de Luiz Cruls, na antiga Fazenda Bananal. Em torno do local escolhido foram traçados os limites do novo Distrito Federal, com uma área de aproximadamente $5.000 \mathrm{~km} 2$.

Ainda em 1955, o presidente Café Filho aprovou o sítio e a área da nova capital, entre os rios Preto e Descoberto, abrangendo três municípios goianos: Planaltina, Formosa e Luziânia.

Mas foi somente em 1956, no governo de Juscelino Kubitschek, que se materializaria a "aspiração nacional” e a concretização de iniciativas voltadas para a construção da nova capital. Em setembro desse ano, foi sancionada a Lei $n^{0} 2.874$, que dispunha sobre a mudança da capital federal e criava a Companhia Urbanizadora da Nova Capital do Brasil, NOVOCAP (responsável pela construção e urbanização da futura cidade). Foi publicado o edital do Concurso para a escolha do melhor projeto para a Nova Capital do Brasil.

JK, imbuído da idéia de promover a dinamização do interior do Brasil e integrá-lo ao projeto de desenvolvimento do país, transforma a construção de Brasília na meta-síntese do seu governo, definindo, inclusive, o dia previsto para a inauguração da nova capital brasileira, 21 de abril de 1960. Nesta data, Brasília foi inaugurada e oficialmente reconhecida como a capital do Brasil, segundo Fernando Fonseca Oliveira.

\section{OS PROJETOS PARA A NOVA CAPITAL}

De acordo com Fernando Fonseca Oliveira, os primeiros registros oficiais que apontam para a criação de um lago, para compor a paisagem da nova capital, vêm dos estudos propostos pela Comissão de Localização da Nova Capital do Brasil, mais 
especificamente da Subcomissão de Planejamento Urbanístico, em 1955. Essa subcomissão era constituída pelos professores Raul Pena Firme, Roberto Lacombe e José de Oliveira Reis. No estudo, os urbanistas conceberam a formação de um Lago em torno da cidade, por meio da construção de uma Barragem no Rio Paranoá.

O memorial Preliminar dos estudos produzidos pelos urbanistas justifica, da seguinte maneira, a existência do Lago:

Projetou-se uma barragem a jusante do rio, que o transforma num lago ornamental, destinado aos esportes náuticos, limitado pelas margens dos rios Bananal e Gama, transformadas em praias artificiais, cobertas por buritizal, numa extensão aproximadamente de dez quilômetros, obtendo-se este motivo paisagístico de encantadora apreciação, que forma com os parques naturais, a serem protegidos, uma agradável atração para a cidade.

Em 1956, após o lançamento do Edital do Concurso que previa a construção de Brasília, 26 projetos foram inscritos. Desses, apenas 10 foram escolhidos para posterior classificação. Os projetos deveriam considerar as singularidades do sítio escolhido e prevê, em seus estudos urbanísticos, a existência de um lago. O aproveitamento paisagístico, que a formação do lago iria promover, era um dos aspectos a ser considerado pelos participantes do concurso.

Em 18 de outubro de 1956, as obras de represamento do Rio Paranoá já tinham sido iniciadas.O sítio escolhido para a cidade possuía as condições naturais para a formação desse lago. Localizava-se próximo à confluência dos rios Torto e Gama que formavam o Rio Paranoá. O aproveitamento desses cursos d'água e seus principais contribuintes foram os responsáveis pela formação do lago, os quais, pela declividade natural do sítio, corriam para Leste, indo em direção às águas do Rio São Bartolomeu, por uma garganta onde se previa o represamento.

O Lago Paranoá, que resultou desse represamento na cota 997 (depois cota mil) acima do nível do mar, foi um elemento definidor do sítio urbano previsto para a edificação de Brasília e marca registrada da paisagem que deveria compor a nova capital. Os dois braços do lago, formadores das penínsulas Norte e Sul, envolvem uma área central triangular, de característica plana, destinada à edificação do Plano Piloto de Brasília.

Nos projetos selecionados é possível identificar a presença marcante do lago como componente urbanístico integrado ao contexto da cidade a ser erguida, inclusive com a 
previsão da ocupação da margem Leste das penínsulas do lago, encontradas nas propostas de Artigas e Equipe e no de Baruch Milman e Equipe.

O plano apresentado pelo Escritório MMM Roberto, que ficou em terceiro lugar no concurso, também apresentou uma proposta de lago bem integrada e articulada com a estrutura urbana pretendida para Brasília. Estava prevista uma rodovia, que passaria próxima às extremidades do lago, bem como áreas para clubes náuticos, embaixadas e grandes residências e a Norte dessa via, junto a um enseada no Lago Paranoá, o Parque Federal, com o conjunto monumental e simbólico dos principais edifícios do Governo.

Vale observar que até o leitor menos entendido em questões de planejamento urbano percebe, numa rápida análise dos projetos concorrentes, como o Lago Paranoá exerce uma influência marcante sobre as propostas urbanísticas apresentadas. É o lago que define o contorno urbano que a nova capital deveria ter. Até mesmo projetos como o de Milton Ghiraldini, rigidamente ortogonal, teve que incorporar em seus ângulos retos a configuração que o lago prevê para o sítio urbano de Brasília.

\section{LAGO PARANOÁ}

O Lago Paranoá artificial formado pelas águas represadas do Ribeirão Paranoá com cerca de $80 \mathrm{~km}$ de perímetro, $5 \mathrm{~km}$ de largura e profundidade de até $30 \mathrm{~m}$. É uma das maiores opções de diversão e esporte para os brasilienses. Representa um imenso espelho d’água às linhas arquitetônicas de Brasília.

O primeiro enfoque que se apresenta remete ao viés histórico-ambiental da cidade. Um hipotético processo de licenciamento ambiental de Brasília remontaria aos estudos preliminares da Missão Cruls, de 1893, que em primeira aproximação, fez a escolha do sítio para implantação do grande empreendimento da capital do Brasil.

Já naquela oportunidade, o botânico Glaziou, integrante da Missão, deteve-se na Bacia do Rio Paranoá, argumentando de forma entusiasmada sobre a conveniência da instalação de uma cidade naquela localidade. Foi também Glaziou quem primeiro especulou sobre a existência, no passado, de um lago natural onde, hoje, localiza-se o Lago Paranoá, passando a recomendar a “obra de arte” que viabilizaria o corpo hídrico que 
haveria de suprir a futura capital quanto às necessidades de abastecimento de água, navegação, abundância de peixes e lazer.

Em 1953, Getúlio Vargas sancionou a Lei nº 1.803, que estabeleceu critérios para os estudos definitivos para a escolha do sítio da nova Capital Federal, destacando-se como parâmetro a população base de 500.000 habitantes.

Como os trabalhos preliminares da Missão Cruls não foram suficientes para atestar a viabilidade ambiental do empreendimento, seguiram-se, em 1955, os estudos detalhados constantes do Relatório Belcher, que especificou e trouxe novos argumentos que possibilitaram, posteriormente, a escolha do Sítio Castanho, ocorrida segundo os critérios da Lei $n^{0} 1.803$ - a área continha grande parte da Bacia do Rio Paranoá -, como local adequado para a implantação de Brasília. Nesse relatório, foram enfatizadas as facilidades da drenagem para aproveitamento do reservatório, tanto para suprimento de água como para geração de energia, mas é importante destacar que, na descrição do Sítio Castanho no Relatório Belcher, não há referência à criação de um lago a jusante da cidade, nos modelos do que viria a ocorrer.

Numa época em que nenhuma outra cidade brasileira havia ainda merecido tantos estudos de viabilidade, esses dois momentos mostram estudos de viabilidade, esses dois momentos mostram estudos que guardam semelhanças com os EIA/RIMAS (Estudos de Impacto Ambiental), que só viriam a ser adotados no Brasil cem anos depois do Relatório da Missão Cruls, a partir da década de 1980.

Feita a escolha do sítio, foi necessária a elaboração do plano urbanístico que deveria adequar-se às condições ambientais da área, momento em que também foi determinado pela Subcomissão de Planejamento Urbanístico, constituída pelos professores Raul Pena Firme, Roberto Lacombe e José de Oliveira Reis, em 1955, que o plano deveria ter como uma de suas condicionantes o Lago Paranoá, que, após o seu enchimento, atingiria a cota de mil metros acima do nível do mar.

Essa decisão foi importante, não apenas porque determinou a própria existência do lago, mas também por que criou um compromisso indelével da cidade para com o corpo hídrico lêntico que passaria a existir a jusante da mancha urbana. Em outras palavras, Brasília teria que ser sustentável, sob pena de perder o lago, o mais significativo patrimônio da escala bucólica do projeto modernista que surgia. 
Dessa forma, o Lago Paranoá tornou-se o maior e mais importante indicador ambiental da cidade e, em sendo assim, preservar o lago e Brasília passou a ser rigorosamente a mesma coisa.

Retomando o hipotético processo de licenciamento ambiental, somente com a apresentação do plano urbanístico acompanhado das condicionantes ambientais dos relatórios da Missão Cruls, da firma Belcher e demais estudos complementares, poderia ser atestada a viabilidade ambiental do empreendimento. Com a escolha do Plano Piloto de Brasília, de Lúcio Costa, provavelmente isto teria ocorrido, e restaria ao empreendedor o atendimento das exigências da "licença ambiental prévia” que, dentre outros aspectos, certamente exigia a apresentação dos projetos executivos de abastecimento de água, drenagem pluvial e esgotamento sanitário, enfim, todos os projetos de infra-estrutura, para que fosse autorizada a instalação da futura capital, assim como o sistema de monitoramento ambiental que acompanharia a implantação do empreendimento, visando a assegurar os cuidados necessários para que a cidade e o lago não ficassem reféns dos impactos ambientais previsíveis em uma obra desse porte.

Particularmente, a limitação da população residente em Brasília em 500.000 habitantes e a definição da existência do lago a jusante da cidade deveriam merecer rigoroso controle, exigindo, certamente, uma sofisticação no planejamento e monitoramento da implantação e operação do empreendimento, quanto à ocupação e ao uso do solo, o que hoje se caracterizaria como "gestão ambiental urbana", segundo Fernando Fonseca Oliveira.

\subsection{A Obra da Barragem}

O edital para o concurso do plano urbanístico de Brasília foi lançado em setembro de 1956. Além da proposta urbanística para a cidade, os concorrentes deveriam propor soluções que previssem o abastecimento de água e energia elétrica, bem como outros serviços básicos a população. A existência de um lago artificial, que circundava a nova capital do país, era um dos pontos comuns a todos os projetos que participaram do concurso nacional. 
Já em 1950, o Relatório Belcher indicava o Rio Paranoá como o curso d’água da região mais adequado para a instalação de uma usina hidrelétrica, para a geração de energia para a futura cidade, devido ao desnível existente entre a sua cabeceira e sua foz. No caso do Lago Paranoá, a sua função também era paisagística, pois estava proposto como elemento urbano da cidade.

A história do Lago Paranoá pode ser recuperada na articulação entre a paisagem e modos de viver, que existiam anteriormente à construção de Brasília, e a nova paisagem e modos de viver forjados com a criação do lago, já que ele não existia, como referência geográfica, para os moradores da região.

O rio estabelecia o limite entre os municípios goianos de Luziânia e Planaltina, cujas terras e imóveis rurais foram desapropriados para comporem o território do Distrito Federal. As terras foram desapropriadas pelo governador do estado de Goiás à época, José Ludovico de Almeida, pelo Decreto $n^{\circ}$ 480, de 30/04/1955, considerando sua utilidade, necessidade pública e conveniência social. Não foram objetos de desapropriação os núcleos urbanos goianos que já existiam: Planaltina e Brazlândia. Posteriormente em fevereiro de 1957, quando se transmitiu a posse, domínio direto e ação dos imóveis rurais dessa região de Goiás, à NOVACAP, foram registradas 19 fazendas, subdivididas em glebas e posses, e registrados também sete imóveis rurais e benfeitorias.

A desapropriação do trecho relativo ao Sítio Castanho, em que seria instalada a nova capital federal, ocorreu por iniciativa do Governo de Goiás. Com a promulgação do decreto de desapropriação, a cidade de Planaltina e as terras que pertenciam juridicamente ao seu município foram alvo de intensa especulação, já em 1955. O apoio oficial do Estado do Goiás à implantação da nova capital servia de argumento para que especuladores constrangessem muitos dos proprietários a venderem suas terras. Na época, quem não se posicionasse a favor da empreitada em taxado de atrasado. A complexa situação fundiária do Distrito Federal remonta, também, a esta etapa da história da implantação de Brasília. Ainda são necessários estudos mais aprofundados para uma melhor compreensão deste contexto.

A historiografia que trata do Centro-Oeste, no século XVIII, tem abordado esta região por oposição às cidades mineiras do século XVIII, descritas em sua opulência e riqueza. Essa abordagem foi, de alguma forma, incorporada ao discurso oficial para a construção de Brasília, quando substituindo-se a baixa densidade demográfica pela idéia do despovoamento, foram utilizadas as noções de vazio e atraso da região como justificativa 
para a construção da cidade. Este recurso, ainda hoje, recorrente nas versões sobre a história da cidade.

Contrariamente às idéias veiculadas, no local selecionado para a instalação da nova capital federal, mais especificamente no local definido para a construção da barragem, estavam instaladas chácaras e famílias que faziam parte de uma comunidade maior, com referências estavam instaladas chácaras e famílias que faziam parte de uma comunidade maior, com referências, principalmente, em Planaltina. Nesta localidade, entre 1922 e 1930, experimentavam-se consideráveis atividades comerciais: charqueada, indústria de beneficiamento de couro, arroz e café e cinema.

Entre as fazendas desapropriadas encontrava-se a Fazenda do Paranoá. Às margens do Rio Paranoá habitavam famílias cujo modo de vida estava inserido na dinâmica social dos municípios goianos existentes à época da construção, com fortes ligações com a cidade de Planaltina, o núcleo urbano mais próximo.

Seu Sebastião, nascido em 1910, na região do Rio Paranoá, recupera a antiguidade da possa da terra.

-E essa terra aí era de quem?

-Era tudo de meu pai. Esse homem, é, era irmão dos meus avô, esse que foi registrar essa terra lá em Goiás Velho, isso eu acho eu não era nem nascido. Mas nesse tempo Luziânia não tinha, eu acho que não tinha cartório suficiente, foi. É porque Goiás já era mesmo, a capital de Goiás. Foi um tempo muito antigo. A irmandade que é dono dessa terra aqui, era doze “home”. Um deles foi lá em Goiás Velho, registrou essa fazenda toda aqui. Essa daqui ainda vai muito mais longe, pro lado de Sobradinho de São Bartolomeu, do lado de lá do Paranoá, a fazenda é muito grande, acho que vai até perto dessa fronteira aí da Papuda, tudo ela ia. Mas foi debuiando, assim como quem debuia uma espiga de milho, foi. Uns tiravam um pedacinho daqui, outros tirava um pedaço de um "dacolá”, tirava mais outro pedacinho "enterava" a dele e por aí foi minuindo, minuindo. A Fazenda Paranoá era muito grande.

A dinâmica social dessas famílias estava marcada por momentos de interação e encontro em que as festas, como a do Divino Espírito Santo e do Muquém ( Louvor a Nossa Senhora da Abadia), eram muito esperadas pela maior parte das pessoas, que cobriam longos caminhos, de até sete dias a cavalo, para poderem participar desses 
momentos de encontro. Reza de terço, ladainhas, catiras, folias faziam e fazem parte das referências dos antigos moradores de Goiás.

Os relatos dos antigos moradores da região do Paranoá recuperam tradições e hábitos, transmitidos ao longo do tempo, que refletem o conhecimento das potencialidades da flora e da fauna do Cerrado, de onde retiram o necessário para viver. Nesse sentido, podemos perceber uma cultura do viver com o necessário por oposição ao viver com opulência.

- Plantava milho, feijão, arroz, cana, mandioca, engordava porco. Tinha gado, uns tinha outros não. Fazia rapadura, fazia açúcar de fôrma. Não existia lâmpada, essas coisa de luz...fazia azeite mamona, socava num pilão, a gente socava bem socadinho, cozinhava, tirava o azeite e punha nas garrafas. Usava esses remédios caseiros, aquela losna, aquela sete-dor, era quina do cerrado. Quina servia pra dor-de-cabeça, pra anemia. Tinha antigamente uma febre amarela, matou muita gente nessa região. Chovia muito, tinha uma época que, às vezes, vinte dias, um mês sem ninguém nem ver o sol. Mês de dezembro, chovia muito. O pessoal desmatou, tirou as árvores, acabou com tudo né. Naquele tempo tinha muita árvore, muito mato, muito cerrado... tirou tudo, parece que ressecou. No mato, no cerrado, tinha fruta. Tem o araticum tem o pequi, esse é o nativo do cerrado. Tinha mangaba, bacupari.

A construção de Brasília, e em especial a construção da barragem, não só introduziu modificação na paisagem da região, nos hábitos, tradições e identidades das populações, como também acirrou o processo de fragmentação da terra e trouxe tecnologias, que nem sempre foram adequadas ao ritmo de vida dessas populações. Por outro lado, colocou essas mesmas populações em contato com as facilidades, como serviço médico e escolas disponibilizados no acampamento, que antes estavam disponíveis apenas em Planaltina.

Antigamente não usava o campo, não usava o campo pra plantio, era só terra de plantio, terra de matas. Desmatava, queimava e plantava. Aquele tempo não existia adubo assim. A terra era fértil, a terra de cultura. E então a gente plantava milho, arroz, o feijão. E a terra de campo era só para pasto, pro gado, cavalos. Depois da construção de Brasília modificou tudo, cada um fechou o que era seu, outros venderam,. Foi apertando mais. Que hoje ninguém pode criar, que cria assim, quem tem o pasto fechado mesmo. Se plantar ainda dá. Mas hoje tem que ser tudo com adubo que não tem mais terra de cultivo, não planta mais o porque onde desmataram, plantaram capim. 
Quando começou Brasília, a gente já morava aqui. A gente não comprava quase nada, a gente tinha de tudo. Só comprava o sal, às vezes o açúcar, mas a gente tinha rapadura e tinha mel. O pessoal da barragem, que hoje é o Paranoá, eles vinham de lá pra cá, vinham comprar fruta, a gente não vendia, dava. Porque aqui tem fatura, tem muito né? Aí eles vinham pra cá no final de semana comprar galinha, comprar ovos.

A produção dessas famílias goianas que moravam às margens do Rio Paranoá, foi importante inclusive para a própria sobrevivência dos operários dos acampamentos da barragem e suas famílias, seja pela compra costumeira de alimentos, seja pelas relações de compadrio e vizinhança estabelecidas. A inexistência do lago, como barreira física aos antigos trajetos e percursos utilizados pelas populações originais da região, permitia também que sua produção fosse vendida em outros acampamentos, especialmente aquele para construção do Palácio da Alvorada.

Eu passei a conhecer os goianos porque a gente sempre era solteiro, a gente trabalha aí, naquele tempo aí, num sei, num existia uma mulher, um cachorro, não existia isso não, em Brasília! Era só os homens trabalhando né? Daí nos domingos, algum domingo que a gente tinha uma folga, a gente tinha aquela vontade de sair para chácara, era aquela paixão danada, saí, só ficava naquele barulho de máquina, aí começava a sair. Os primeiro, mas perto era esse Velho Sebastião. Chegava lá, encontrava com ele, ia conversando devagarinho com ele, até ir acostumando com a gente devagarinho, também. Que naquele tempo ele tinha cisma desse povão né? Ele ia acostumando, com aquela calma, que eles tinha aqui, que quando Brasília estourou trouxe gente de toda parte.

As relações entre os operários e as famílias goianas não estavam isentas de conflitos e contradições. Por um lado, as noções de vazio e atraso, divulgadas pela propaganda oficial, implicavam atitudes entendidas pelas famílias goianas como desrespeitosas, como o acesso indiscriminado às propriedades e retirada de frutas e animais domésticos por parte de alguns trabalhadores. Por sua vez, a experiência de vida por outros trabalhadores, do encontro e das trocas por moradores originais da região, cujo modo de vida e tradições culturais se assemelhavam àquelas deixadas por muitos dos estados de origem, refletiam a permanência do mundo rural na cidade moderna.

O início da construção de Brasília ocorreu no final do ano de 1956, quando foram iniciadas as obras do Catetinho e instalados os primeiros acampamentos, ainda de barracas de lona, na área destinada à Esplanada dos Ministérios. 
Conforme o Diário de Brasília, as primeiras iniciativas para a construção da barragem dão do final do ano de 1956, com o início do processo de represamento do Rio Paranoá e seguiram as seguintes etapas:

07/1957 - conclusão do anteprojeto da usina hidrelétrica;

12/1958 - início das obras da ensecadeira do desvio;

01/1959 - conclusão da ensecadeira do desvio e conclusão do vertedouro;

07/1959 - fechamento das comportas e impermeabilização;

11/1959 - obras da usina já iniciadas.

A usina hidrelétrica teria a capacidade de produzir 27.000 kw. A água necessária para a geração de força viria do represamento do Rio Paranoá, descendo por tubulação até a estrutura da usina, montada abaixo da barragem que, ao represar o rio, formou o lago que hoje conhecemos. O Rio Paranoá era formado por uma série de outros rios, córregos e nascentes que o alimentavam e que formavam a Bacia do Paranoá.

-O rio Paranoá, ele começava lá em cima. Aí vai, entra aquele que vem do Gama, aquele que vem de perto do Catetinho para cá. Tem o do Pica-pau, tem umas seis perna aí pra frente. O que vem do Pica-pau é o taboquinha. Depois vem aqueles que vem da Água Mineral, tem o rio do Torto, Tem muitos que cai aqui dentro. Todos eram rio, pequenos, mas rio. Aqui deve ter umas seis a oito nascente de água aqui dentro. Mas como fez a barragem, cercou, acabou. Ele veio tubulando, por tubulação (...) porque a barragem segurou todos.

-E o Paranoá era fundo?

-Não, ele sempre não foi de grande proporção de água, só que ele tinha água mais que o São Bartolomeu. São Bartolomeu ganhou em distância. O Paranoá aqui tinha peixe adoidado, a coisa que mais tinha aqui era peixe. Olha, aqui tinha muito piau, piau três pinta, tinha um tal de piaupara, dourado desse tamanho ó! Dourado imenso. Se você encontrar um desses goiano. "véio", pergunta. E você pescava não era igual a hoje, nós pesca matando tudo sabe (refere-se ao uso de redes). Naquela época eu pegava aqui o da janta, amanhã o do almoço, tinha demais.

Para a construção dessa barragem foi montado um acampamento no início de 1957. A história desse acampamento tem peculiaridades em relação aos outros criados à época, 
seja pelas características do trabalho realizado, seja pelas relações forjadas entre os trabalhadores e os goianos, moradores nativos da região.

O acampamento para construção da barragem foi montado pela NOVACAP para abrigar os operários e engenheiros das empresas construtoras. Relatos dos antigos operários indicam que o primeiro acampamento foi montado na área que hoje está inundada pelo lago. Posteriormente, à medida que as obras da barragem avançavam, foi necessário transferir o acampamento para uma cota mais alta, local que, posteriormente, ficou conhecido como Vila Paranoá e que deu origem à cidade do Paranoá que conhecemos hoje.

-Eram seis firmas tudo nesse setor da barragem aqui! Seis companhias! (...) Tinha a Novacap, que comandava as outras né e tocava o serviço também, tinha a Planalto, que era dos americanos; tinha a Portuária, era de terra, tinha a Geotec, injetação de concreto e cimento; tinha a Rodobrás e tinha a CCBE, seis. Eram seis firmas só nesse setor do Paranoá ai.

A estrutura do acampamento do Paranoá seguiu o modelo adotado de segmentação, conforme a especialização do trabalho. Havia casas para os engenheiros e suas famílias, casas para os mestres de obras e instalações para os operários, cuja vinda das famílias não era incentivada. O controle sobre a vinda das famílias dos operários não foi tão efetivo, o que pode ser verificado no grande número de vilas, como vilas do Sapo, Parafuso, Piauí, dos Mineiros, formadas ao redor do acampamento e que abrigavam as famílias dos operários solteiros e a mão de obra prestadora de pequenos serviços. Neste sentido é necessário relativizar a ilegalidade desses assentamentos, uma vez que também eram necessários à manutenção da engrenagem, que era a construção da cidade. Para trabalhadores diferenciados, moradias, alimentação e jornadas de trabalho diferenciadas.

-Tinha o acampamento. Muitos homens, muito pião. Parece que já tinha duzentos alojamentos já feitos; cada alojamento parece que tinha quatrocentas camas.

- Tinha tudo separado assim, a casa dos engenheiros, dos encarregados, as casas dos fiscais e dos apontadores. Tudo era separado.

-Era como a comida: a primária era de peão, a intermediária já era de fiscal, a "staff" era de engenheiro, aquela outra que era mais separada, já era dos donos... Era tanta coisa. Era tudo separado. 
As atividades desenvolvidas pelos trabalhadores desses acampamentos concentravam-se nas obras das fundações da barragem e na exploração de pedreiras. Durante a construção foram montadas diversas pedreiras para a obtenção de matéria prima necessária às obras da construção civil, como areia, cascalho e brita. Em alguns casos, a exploração foi arrendada a particulares e, em outros tocadas pelas próprias construtoras. Conforme o relato dos entrevistados, a produção destes materiais desdobrava-se em várias etapas de processamento do material bruto em que trabalhavam, desde os operários fichados nas empresas, trabalhando nos procedimentos que envolviam explosivos e britadores, até mulheres e crianças que quebravam as pedras em tamanhos reduzidos que o maquinário de grande porte não processava. O cotidiano é marcado pelo barulho das explosões e pelo deslocamento de grandes massas de terra.

O intenso debate nacional sobre a construção de Brasília gerou inúmeros questionamentos de parlamentares sobre a administração das obras pela NOVACAP. Em 10/11/59, com a aproximação do prazo para inauguração de Brasília, o Deputado Elias Adaime discursa em plenário sobre o mal encaminhamento das obras e, por isso, a impossibilidade de inauguração da cidade na data estabelecida, defendendo a instalação de uma CPI. Suas denúncias apresentavam provas de desvio de material de construção, desaparecimento das madeiras retiradas da região do lago, concessão de obras e serviços para apadrinhados e aumento nos custos da obra. O último ponto estava relacionado diretamente com a barragem, pois havia indícios de que uma segunda barragem estava sendo feita devido a um vazamento de água. Em resposta ao Deputado, o Presidente da NOVACAP explica que não havia problemas com a represa, mas sim que estavam sendo usadas técnicas diferentes.

Apesar de ser uma obra fundamental para a própria configuração da paisagem da cidade, não há registros explícitos nem na Revista Brasília de divulgação oficial da NOVACAP, nem no Diário de Brasília sobre a data precisa da inauguração da barragem, o que foge do padrão adotado para a cidade, pois, na medida em que as obras eram concluídas, eram amplamente divulgadas.

As datas registradas no Diário de Brasília fazem referência ao fato que já em novembro de 59 haviam começado as obras da usina hidrelétrica. Os trabalhadores entrevistados relembram, no entanto que as obras começaram depois da inauguração da cidade e que seu pleno funcionamento só foi ocorrer em meados dos anos 60 . 
Em 21 de abril de 1960, quando Brasília foi inaugurada, do Plano Piloto elaborado para a cidade por Lúcio Costa existiam apenas o traçado básico das principais avenidas, o Palácio da Alvorada, o Hotel de Turismo, a Esplanada dos Ministérios com seus prédios principais, a Rodoviária, algumas superquadras na Asa Sul, as estruturas metálicas da Catedral e o Lago Paranoá.

Após a inauguração de Brasília, momento em que o grande canteiro de obras é transformado em Capital Federal, as vilas até então toleradas e os acampamentos de construtoras, localidades que aglutinavam indivíduos próximo aos locais de trabalho, passam a ser vistos como invasões a serem erradicadas. No caso dos acampamentos, alguns, como a Vila Paranoá e a Vila Planalto, tem a sua estrutura reduzida.

No Paranoá, com a conclusão definitiva das obras da barragem e da usina, as construtoras se retiraram do acampamento que passa a ser ocupado pelos operários e suas famílias, e pelos moradores das vilas ao redor. A saída das companhias construtoras implica retirada de algumas edificações que marcavam a organização e a rigidez do acampamento original. Por outro lado possibilitou a configuração de uma nova estrutura em que se reforçaram os laços de vizinhança. Data deste período a construção da Igreja São Geraldo. As primeiras missas, ainda no acampamento, eram realizadas num dos barracões geridos pela NOVACAP. Com o passar do tempo surge a necessidade de um local mais adequado para a celebração da missa.

A Vila Paranoá foi desmontada da noite para o dia e dela só restaram as árvores plantadas pelos moradores ao longo dos anos, algumas edificações que abrigavam instituições de assistência aos moradores e a Igreja São Geraldo, definida pelos moradores mais antigos como forma de manterem vivas a memória da Vila Paranoá e da luta pela fixação. A área foi transformada no Parque Urbano do Paranoá, que também compõe a Região Administrativa do Paranoá, e a Igreja foi tombada como patrimônio histórico do Distrito Federal.

\subsection{Bacia do Lago Paranoá}

A caracterização da bacia do Lago Paranoá, empreendida abrangeu os principais cursos d’água da rede de drenagem da Bacia do Paranoá, quais sejam: Ribeirão do Torto, 
Ribeirão do Gama, Ribeirão do Riacho Fundo e Ribeirão Bananal; a partir dos dados hidrológicos que compõem as séries históricas e, no caso da unidade hidrográfica do Lago Paranoá, por meio de processos de regionalização.

\section{Bacia do Lago Paranoá - Carta de Drenagem}

\section{Bacia do Lago Paranoá - Carta de Drenagem}

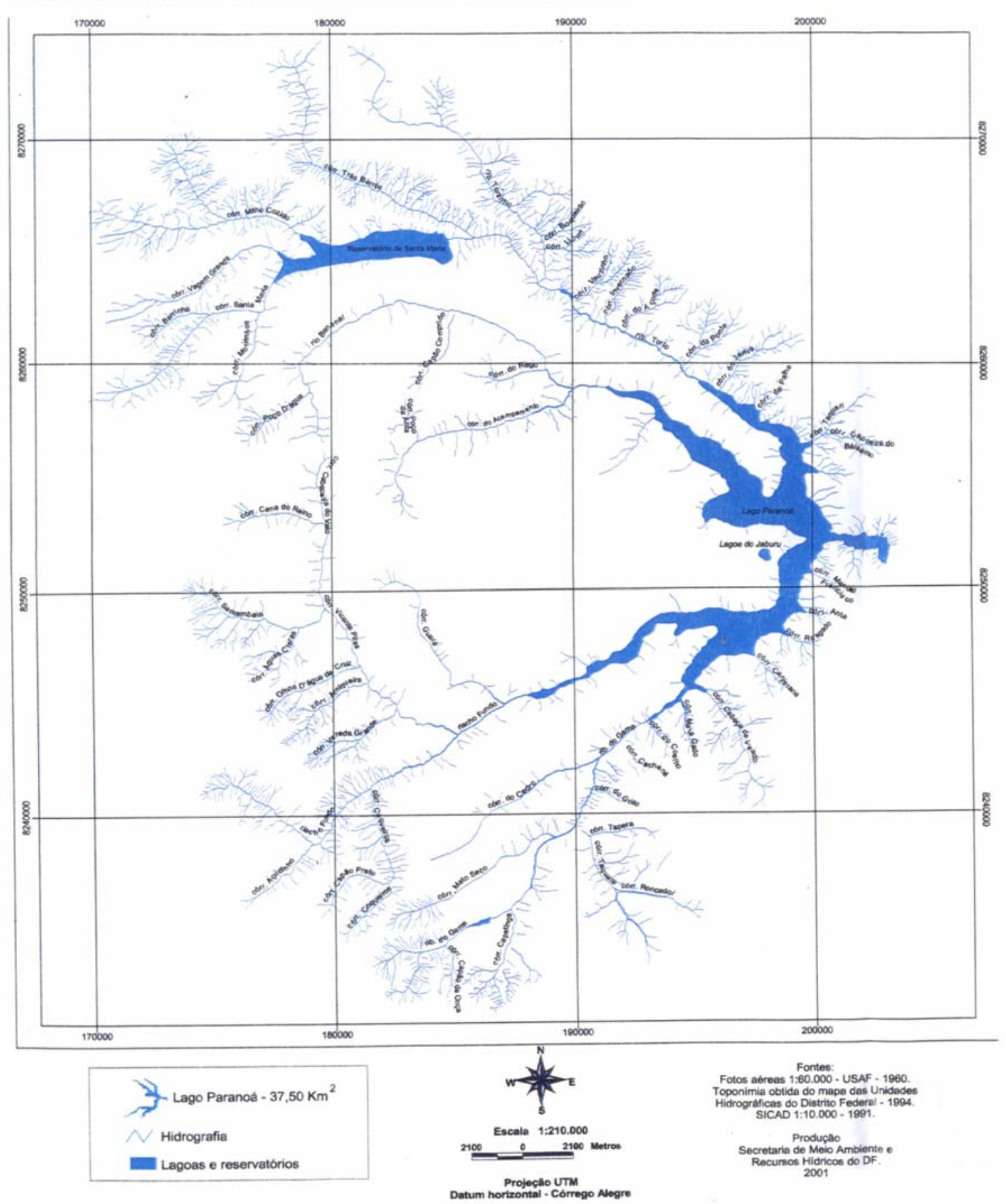

Figura 2 - Olhares sobre o Lago Paranoá, 2001, p.49 


\subsubsection{Ribeirão do Torto}

O Ribeirão do Torto possui uma área de drenagem de 249,76 km2; seu curso principal mede cerca de $20 \mathrm{~km}$ e apresenta uma declividade média de 7,8 m/km. Não possui mais um regime hídrico natural, pois está alterado pela presença das barragens de Santa Maria e do Torto. Seus principais afluentes são os córregos Tortinho e Três Barras, juntamente com o ribeirão de Santa Maria. O ribeirão do Torto deságua diretamente no Lago Paranoá, com uma vazão média de 2,89 m3/s

\subsubsection{Ribeirão do Gama}

O Ribeirão do Gama possui uma área de drenagem de 142,40 km2 e seu curso principal mede cerca de $14 \mathrm{~km}$. A bacia compreende os seguintes cursos d’água: Córrego do Cedro, Córrego Mato Seco, Córrego Capetinga e Córrego Taquara; seus principais afluentes. Deságua diretamente no Lago Paranoá, com uma vazão média de 1,85 m3/s.

\subsubsection{Ribeirão do Riacho Fundo}

A sub-bacia do Ribeirão Riacho Fundo, contribuinte do Lago Paranoá, possui uma área de 225,48 km2 e a extensão de seus curso principal é de $13 \mathrm{~km}$. Seus principais afluentes são os córregos Vicente Pires e Guará, pela margem esquerda e o Córrego ipê, pela margem direita. A sua vazão média é de 4,04 m3/s.

\subsubsection{Ribeirão Bananal}


A sub-bacia do Ribeirão Bananal, ocupando uma área de 127,74 km2, está praticamente situada dentro do Parque Nacional de Brasília. O Ribeirão Bananal tem uma extensão de 19,1 km e deságua diretamente no lago Paranoá. Seus Principais afluentes são os córregos do Poço Fundo e do Acampamento. Sua vazão média é de 2,51 m3/s.

\subsubsection{Lago Paranoá}

A sub-bacia do Lago Paranoá ocupa uma área de 288,69 km2, funcionando como bacia de captação dos principais cursos d’água que drenam o sítio urbano da cidade de Brasília. A unidade lacustre, integrante de destaque na paisagem da bacia do Paranoá, resulta de uma antiga depressão inundada, que foi reorganizada pelo planejamento para instalação da cidade.

O Lago Paranoá foi formado a partir do fechamento da barragem do Rio Paranoá, no ano de 1959, represando águas do Riacho Fundo, do Ribeirão do Gama e do Córrego Cabeça de Veado, ao Sul e do Ribeirão Torto e do Córrego Bananal, ao Norte, além de outros pequenos tributários que alimentavam as belas cachoeiras que desciam rumo ao Rio São Bartolomeu.

\begin{tabular}{|ll|}
\hline - & \multicolumn{1}{|c|}{ Lago Paranoá - Características Gerais } \\
\hline - & Área superficial $-37,50 \mathrm{~km} 2$ \\
\hline - & Volume Total $-498 \times 106 \mathrm{~m} 3$ \\
\hline - & Profundidade média $-12,42 \mathrm{~m}$ \\
\hline - & Profundidade máxima $-38 \mathrm{~m}$ \\
\hline - & Perímetro - $111,87 \mathrm{~km}$ \\
\hline - & Largura máxima $-5 \mathrm{~km}$ \\
\hline - & Vazão média afluente dos principais cursos d'água - $11,29 \mathrm{~m} 3 / \mathrm{s}$ \\
\hline - & Vazão média efluente $-19,80 \mathrm{~m} 3 / \mathrm{s}$ \\
\hline - & Tempo de retenção - 299 dias \\
\hline
\end{tabular}

Tabela 1 - Olhares Sobre o Lago Paranoá, 2001, p. 51 
Foram necessárias duas temporadas de chuvas para que as águas do lago atingissem a cota prevista de $1.000 \mathrm{~m}$ acima do nível do mar. Desde então, o lago passou a cumprir o seu destino, de embelezamento da Nova Capital, criando um microclima ao seu redor e oferecendo alternativas de lazer e recreação para a população, transformando-se no mais belo monumento da escala bucólica da cidade.

\subsection{Ilhas do Lago Paranoá}

Existem três ilhas no Lago Paranoá, formadas quando ocorreu o represamento de suas águas, elevadas até a cota 1.00, isolando os topos de pequenas elevações ligadas à margem pela figura topográfica do colo coberto por pequena lâmina d’água.

Segundo a Carta Náutica do Lago Paranoá, elaborada pela Marinha do Brasil, em 1968, elas são chamadas de Ilha do Paranoá, Ilha do Retiro e Ilha dos Clubes.

\subsubsection{Ilha do Paranoá}

A maior delas e está situada entre a ML 4 e a ML 5, no Setor de Mansões do Lago Norte, medindo aproximadamente $110 \mathrm{~m}$ na sua maior largura por $140 \mathrm{~m}$ no maior comprimento, totalizando uma área de $1,50 \mathrm{~m} 2$ há. Sua cota atinge os $1.008 \mathrm{~m}$ acima do nível médio do espelho d’água do lago. Seu afastamento da margem do lago é de cerca de $10 \mathrm{~m}$.

É a ilha mais próxima da margem do lago, o que facilitou, durante muitos anos, o acesso de pessoas e até mesmo de automóveis, criando enorme impacto ambiental e incômodo a vizinhança. A partir 1993, a Associação Pró Lago Norte obteve autorização para realizar o aprofundamento do canal que separava a ilha da margem, que era, na época, de apenas 40cm. Em 1994, o serviço de drenagem foi realizado, aprofundando o canal e criando uma barreira de terra, impedindo o acesso de automóveis à ilha. 
Graças ao seu maior isolamento, a ilha pôde recuperar parte da sua vegetação nativa, atualmente, razoavelmente preservada, apresentando a incidência de mais de 16 espécies de arbustos, dentre os quais, ipê amarelo, chapéu-de-couro, pau-santo e carne-de-vaca; 2 espécies de árvores, ou seja, pau-terra e paineira do cerrado; e 2 espécies de palmeiras, a saber, catolé e licuri.

A Ilha do Paranoá tem sido freqüentada, predominantemente, por pescadores, o que tem gerado menos lixo e danos ambientais do que na ilha vizinha, da ML 7. Apesar de ser bastante próxima da margem, a Ilha do Lago tem poucas praias para banho, apresentando pedras graúdas na orla Nordeste, prevalecendo, nas suas margens, as encostas de barrancos altos, impróprios para o lazer.

\subsubsection{Ilha do Retiro}

Está situada em frente a ML 7, do Setor de Mansões do Lago Norte, medindo no seu comprimento114 m e na maior largura 88 m, somando uma área aproximada de 1,00 ha. Sua cota de altitude é de 1.004 m, estando cerca de 4 metros acima da cota média do lago. Sua distância da margem atinge os 85 m, o que tem poupado a ilha de maiores danos.

Entretanto, durante o período da seca e de abertura das comportas da barragem, quando as água do lago atingem as menores profundidades, os freqüentadores da ilha atravessam, com facilidade, a pequena lâmina d’água, de $50 \mathrm{~cm}$ a 1m, fazendo do trecho da orla confrontante e da própria ilha, verdadeiros espaços de lazer e recreação, sem a menor estrutura para esse uso.

O uso intensivo da ilha para pescarias e diversão de adultos e crianças pode ser constatado, nos finais de semana e nos feriados, pela enorme quantidade de lixo largado no cerrado, sinais de fogueiras, fogões de pedra improvisados. Galhos quebrados e arrancados das poucas árvores existentes, inexistência de ninhos (em decorrência da fuga das aves), além de outros danos, completamente incompatíveis com a vocação da ilha, ou seja, um refúgio da vida silvestre.

A Ilha do Retiro é cercada de praias de pequenos seixos descamados dos quartizitos, o que facilita o acesso de capivaras e lontras, além de outras espécies da fauna local. 
A vegetação da ilha do Retiro é mais exuberante do que a as Ilha do Paranoá, incluindo espécies arbóreas, concentradas notadamente nas porções Sul e Norte. Dentre elas, podem ser encontradas mais de 17 espécies de arbustos, sendo alguns típicos de área úmidas, átis como quaresmeira, piuna e mulungu; mais de 13 espécies de árvores, como jacarandá do cerrado, copa rosa, ipê-verde, barbatimão e mandiocão; e 3 tipos de palmeiras, coco-babão, ariri e catolé.

A Ilha do Retiro e a Ilha do Paranoá são declaradas Reservas Ecológicas,conforme Lei $\mathrm{N}^{\mathrm{o}} 1.612$ de 8 de agosto de 1997, com o objetivo de preservar o ecossistema local, proteger ninhais de aves aquáticas e outros locais de proteção da fauna nativa e garantir proteção às aves migratórias.

Apesar da proteção formal existente, as Reservas Ecológicas no Lago Paranoá encontram-se expostas ao uso descontrolado e ao vandalismo, necessitando de um disciplinamento da visitação e de uma vigilância mais efetiva, tendo em vista que a condição de reserva ecológica impõe o uso indireto.

As espécies da flora nativa, encontradas nas ilhas, revelam a riqueza e a diversidade existentes no bioma cerrado. Uma área de apenas um hectare, originalmente de campo, contém uma enorme variedade de espécies, algumas típicas de áreas úmidas, surgidas com a formação do ambiente lacustre. Dentre as mais de 30 herbáceas encontradas nas ilhas, podemos citar o capim-natal, a maria-pretinha,, o capim gordura e o capim-barba-de-bode, além das espécies de áreas úmidas, tais como barba-de-bode, tiririca, tanchagem, cipó imbé, samambaia, capim navalha e chuveirinho.

\subsubsection{Ilha dos Clubes}

Está situada em frente ao Clube de Golfe, no Setor de Clubes Esportivos Sul, mais precisamente na altura da terceira ponte do Lago Sul.

A pequena ilha é formada por um agrupamento de rochas,com uma área de solo central, onde crescem as piúnas (Ludwigia sp.), as gramíneas e samambaias que lhe dão vida. A Ilha dos Clubes tem cerca de 6 metros de diâmetro e pouco mais de $1 \mathrm{~m}$ de altura, distando uns 50m da margem. 
Em função da sua pequena dimensão, tem servido apenas para o pouso das aves, durante o descanso do vôo ou nos intervalos das pescarias. Suas pedras podem representar perigo para os navegadores menos avisados, o que sugere um certo cuidado na navegação noturna, bem como a necessidade de uma sinalização por bóia ou baliza.

Situação semelhante, de risco à navegação, ocorre na margem Oeste da Península Norte, onde um agrupamento de rochas aflora com as água baixas do lago e se escondem no período da cheia, surpreendendo os navegadores.

Essas formações rochosas não podem ser caracterizadas como uma ilha, pois não são de afloração permanente, no entanto, no período em que se encontram expostas, servem de abrigo e de área de pouso das aves, especialmente dos mergulhões pescadores, garças e socós.

A “ilha temporária”, variando de 2 a 5 metros de diâmetro, está localizada a cerca de 1.000 m da ponta da península, na margem Oeste, no Braço do Ribeirão Bananal, próxima do Clube do Congresso, em frente à QL 16, do Setor de Habitações Individuais Norte.

Com a futura instalação da sinalização para navegação do Lago Paranoá, essa barreira de pedras não pode ser esquecida, devendo ser protegida e anunciada por bóia luminosa.

As ilhas do lago estão cercadas por uma atmosfera de poesia e mistério. Isoladas das margens, guardam parte da vegetação nativa do tempo em que não havia o enorme espelho d’água, mas também ganharam novas espécies e estimulam a imaginação de quem às contempla, dando um ar mais natural a essa majestosa obra dos homens, que é o Lago Paranoá, segundo Fernando Fonseca Oliveira no livro Olhares sobre o Lago Paranoá. 


\section{BRASÍLIA CONGREGANDO DIFERENTES CONTRIBUIÇÕES CULTURAIS}

Brasília continua sendo o centro, local privilegiado, com as melhores salas de espetáculos, escolas de arte, universidades, espaços culturais. Entretanto, as demais cidades do DF vêm conquistando seus espaços, expressando sua cultura e participando, cada vez mais, da construção de uma nova identidade cultural.

O Lago Paranoá sempre esteve presente no processo de formação cultural da cidade. Desde a construção da concha acústica, em atenção ao projeto da escala bucólica de Brasília, até a consolidação dos espaços coletivos e dos clubes da orla, promotores de eventos náuticos, regatas, festas e palco de encontro para o esporte, o lazer, a recreação e o entretenimento.

Com o passar dos anos, a nova geração de arquitetos da cidade, atendendo aos anseios dos brasilienses, idealizaram o Projeto Orla, concebido como espaço cultural, de serviço, comércio e lazer, que deverá integrar, definitivamente, a cidade ao lago, tornando-o cenário do futuro urbanístico de Brasília, e reinaugurando a sua vitalidade dos tempos pioneiros.

\section{Turismo Náutico no Lago Paranoá}

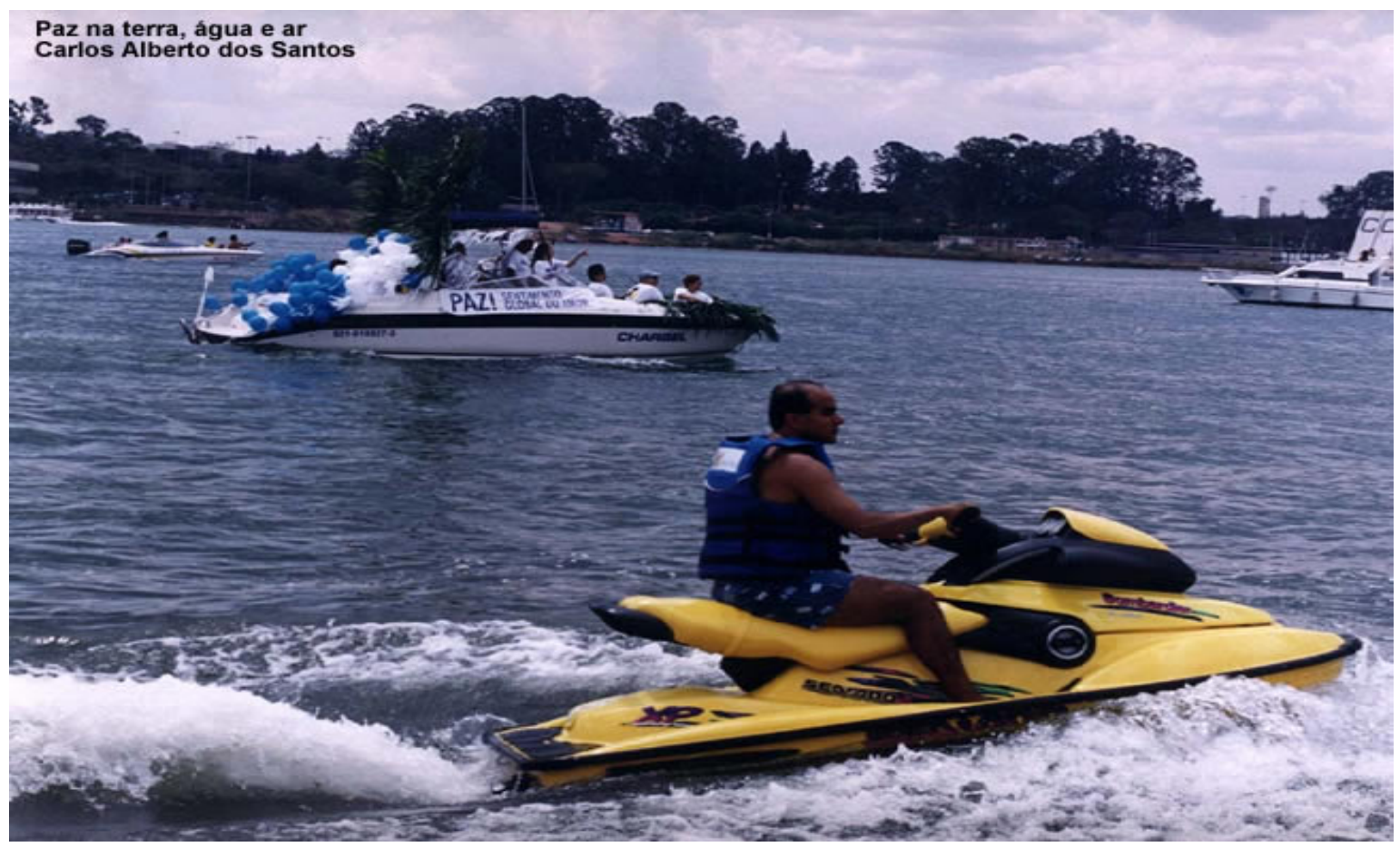

Figura 3 - www.semarh.df.gov.br, 2003 


\section{CAPÍTULO III}

\section{TURISMO CULTURAL}

Quando se fala em lazer cultural em Brasília, a principal imagem que vem a tela mental é o contato do homem com os seus belos espaços e o Lago Paranoá se insere nesse contexto. No entanto, sendo fomentado o turismo cultural e a exploração na orla do Lago Paranoá, Brasília se destacará na mídia mundial num clichê do marketing comercial, elevando a imagem do Patrimônio Cultural da Humanidade. Percebe-se a carência de um real esforço de órgãos de maior competência do Governo do Distrito Federal, para implantação de planos de ação para mobilizar as comunidades e formular conceitos para que resgatem a importância da cultura como parte da vivência do turista na cidade e da população brasiliense em forma ativa, com o objetivo de conhecer e interpretar os valores culturais existentes em estreita inteiração e integração com as comunidades locais com impacto sobre os recursos e ser a base de apoio aos esforços dedicados a preservação e manejo de suas áreas naturais.

É necessário ter em mente que o patrimônio cultural está tão intrínseco ao meio ambiente como o homem está para a cultura. Sob esta perspectiva e a partir de uma forte tendência mundial no mercado turístico para a busca cada vez maior de conhecimentos e experiências culturais legítimas por parte dos visitantes e sobretudo tendo como fato a expressão cultural autêntica de Brasília totalmente integrada ao meio ambiente.

O turismo cultural é aquele que se preocupa com os fazeres humanos, com os valores humanos. As coisas são feitas pelo homem, constituem a oferta cultural, com o objetivo de conhecer os bens materiais e imateriais. O turismo deve levar em conta os bens não materiais como: religião, folclore etc.

\section{MANIFESTAÇÕES CULTURAIS}


No lago de Brasília há um encontro entre os elementos naturais e os elementos culturais. Nas suas águas e em toda sua orla são identificadas manifestações socioculturais, esportivas, religiosas e econômicas, que têm no lago um referencial fundamental. Essas manifestações são elementos culturais de identidade brasiliense materializam a relação da cidade com o lago, utilizando as várias potencialidades que ele abriga.

Existe um entendimento de que o estímulo ao uso, mediante o acesso público e democrático das suas margens, é um dos elementos fundamentais que pode garantir a sua sustentabilidade ambiental e cultural. O uso das águas, dos clubes, dos hotéis e restaurantes, e de outros espaços da orla, reforça e fortalece a relação de identidade da população com o lago, contribuindo para sua preservação e valorização.

Essa valorização se dá com o reconhecimento e a importância que esse bem representa como um todo (área e entorno): desde suas águas, sua vegetação típica, animais; até as edificações de referência histórica, que se encontram em suas margens. Nesse sentido, não basta que haja uma preservação formal, restrita aos elementos edificados. A preservação tem que incorporar tanto a dimensão cultural, quanto a ambiental; o urbano tem que estar em harmonia com o meio ambiente natural que o integra.

Em toda orla do Lago Paranoá é possível encontrar manifestações socioculturais, esportivas e econômicas que contribuem para a sua valorização e importância, e que são mecanismos que promovem, direta ou indiretamente, a sua sustentabilidade cultural e ambiental.

No lago, são identificadas as seguintes manifestações, que apresentamos em três categorias:

2.1. Manifestações socioculturais: procissões de Dom Bosco e Círio de Nazaré, nos meses de agosto e outubro, respectivamente; festas religiosas em homenagem à passagem do ano, realizadas na Prainha, atual Praça dos Orixás; vários eventos náuticos comemorativos, tais como: Semana de Vela de Brasília, Batalha Naval de Riachuelo, Regata do Dia das Mães, Regata 24 horas, entre outros. 
2.2. Manifestações esportivas: prática de esportes (natação, jet-ski, esqui-aquático, navegação a vela, canoagem, windsurf, etc); práticas esportivas educativas, pesca e eventos náuticos. A Capitania dos Portos registrou cerca de 110 eventos náuticos na categoria regata e nautimodelismo no ano 2000. Muitos desses eventos acontecem anualmente e fazem parte de um calendário cativo das manifestações esportivas e náuticas que ocorrem em Brasília.

2.3. Manifestações econômicas: pesca amadora e profissional com fins econômicos, passeios de barco (turismo), serviço de hotéis, bares e restaurantes, etc.

No contexto dessas manifestações devem ser considerados também os clubes esportivos, as áreas de lazer, os restaurantes e os bares existentes na orla do lago, por se constituírem em espaços que viabilizam o acesso a ele. Esse aspecto é relevante, considerando-se que mais de 50\% desses espaços, na orla, estão praticamente entregues ao domínio da iniciativa privada.

.A valoração do Espaço Turístico na Orla do Lago Paranoá, constitui-se em um fator positivo para o desenvolvimento do turismo cultural em Brasília. A leitura e a análise do potencial turístico podem indicar os rumos das ações a serem implementadas pelo GDF no sentido de melhorar a imagem local e captar a sinergia de atrativos pelo fato de Brasília ser o momento mais jovem do Patrimônio Cultural da Humanidade, tombada pela UNESCO (GDF, 1999).

\section{BENS DE VALOR HISTÓRICO CULTURAL}

A demanda turística do Lago Paranoá, aponta como vertente os símbolos históricos e culturais de sua Orla inseridos neste contexto quais sejam: 
3.1. A Terceira Ponte do Lago Sul, Brasília-DF. Ponte JK, iniciada em 2000 e inaugurada em 15 de dezembro de 2002, abrange a satisfação estética e cuidados com o meio ambiente presentes, pela sua extraordinária obra de engenharia e construção.

Além das belezas naturais e das outras construídas pelo homem, ao longo de sua história, o Lago Paranoá ostenta, hoje, a mais bela obra da engenharia civil voltada para o transporte. Trata-se da Ponte JK, inaugurada a pouco mais de um ano..

A ponte é motivo de orgulho nacional, tanto para brasilienses, quanto para todos os brasileiros, pois que é reconhecida e declarada mundialmente, como a ponte mais bonita do planeta na atualidade, conforme Revista Excelência, julho, 2003, p. 25.

\section{A terceira Ponte do Lago Sul - Ponte JK}

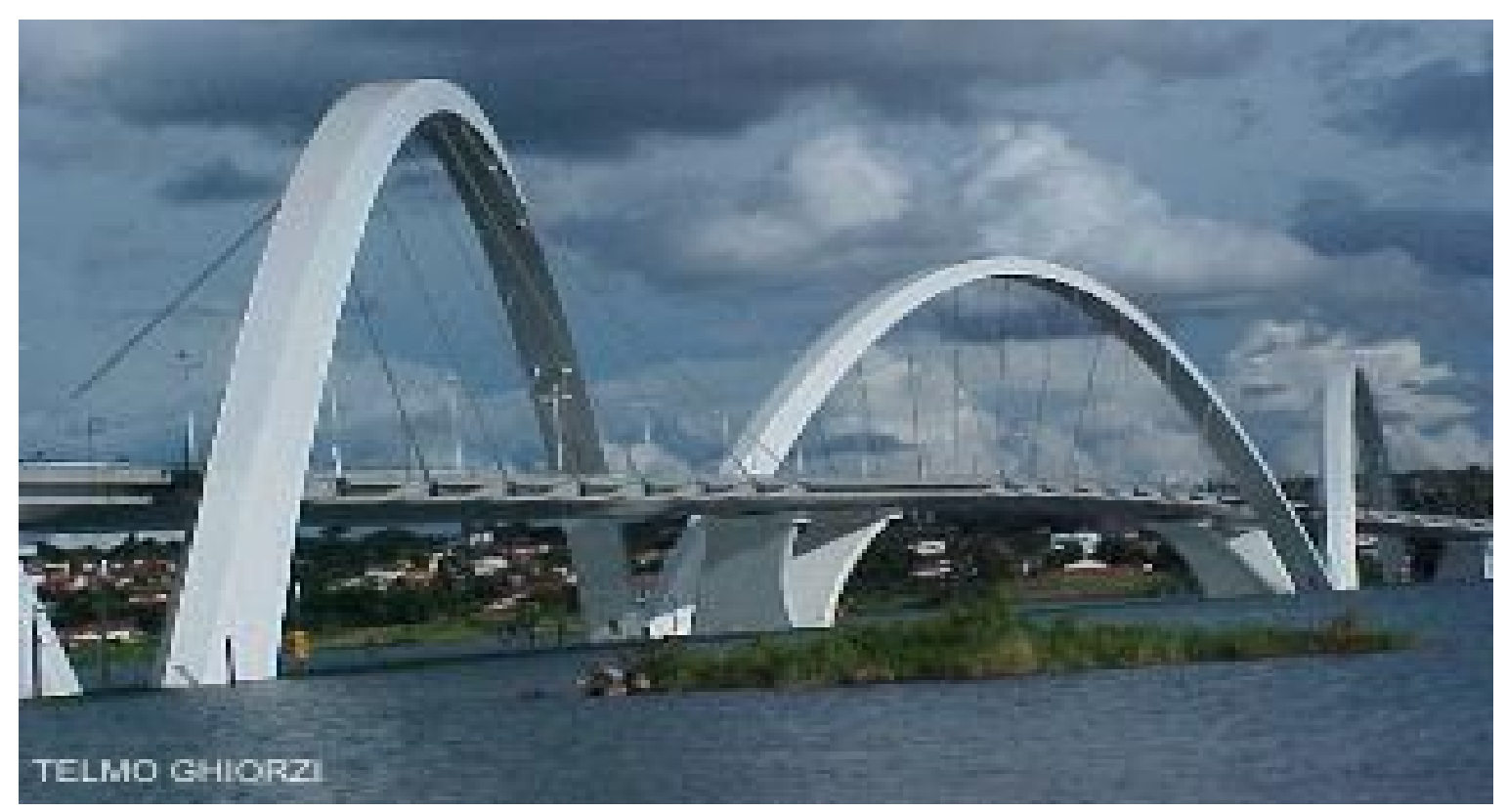

Figura 2 - www.geocities.com/capecanaveral/4274/pontedf.htm, 2003

Não são, apenas, os efeitos óticos causados pela beleza de seus arcos, nem por sua beleza arquitetônica, mas, acima de tudo, os seus efeitos econômicos e sociais, que dão real importância da ponte. Por ela trafegam, diariamente, nos seus dois sentidos, milhares de veículos, com economia de tempo, de dinheiro, com mais tranqüilidade e segurança. 
3.2. A Ermida de Dom Bosco, tem a forma de uma pequena pirâmide com base triangular bastante inclinada, revestida em mármore branco, possuindo uma cruz em metal no seu topo. Está construída sobre uma plataforma de lajes, em uma elevação às margens do Lago Paranoá, com sua abertura triangular voltada para a cidade. No interior do templo está a imagem de D.Bosco esculpida em mármore de carrara, pelos irmãos Arreghini, de Pietra Santra - Itália.

O projeto arquitetônico é de Oscar Niemeyer. Sua tipologia apesar de arrojada possui caracterização simples, despojada de qualquer ornamentação, resultando em monumento bastante singelo e se destaca como espaço de lazer, vista do pôr do sol, apresentação de teatro e outros.

Localizada em sítio ambiental bastante aprazível, às margens do Lago Paranoá, propiciando uma visão privilegiada de todo o Plano Piloto, onde se destacam o Palácio da Alvorada, Eixo Monumental e Esplanada dos Ministérios.

A Capela da Ermida foi construída em homenagem à São João Bosco, tendo sido uma das primeiras obras realizadas pela NOVACAP, inaugurada em 1957, foi o primeiro Templo de Brasília.

Está localizada no ponto de passagem do paralelo 15o., local onde se presume que estaria D. Bosco em seu sonho, que anteviu, em 1883, a construção da capital brasileira no Planalto Central, entre os paralelos $15^{\circ}$ e $20^{\circ}$.

Tombada pelo GDF em 02/03/88, a proteção do templo é extensiva ao seu entorno, abrangendo uma área circular com raio de 100 m, a partir da construção original. A Ermida é um dos elementos de referência histórica e cultural mais importantes de Brasília. Apesar disso, nos últimos anos a área próxima à ermida foi palco de intervenções urbanas desordenadas, especialmente do Condomínio Villages Alvorada, que chegou a ameaçar a área tombada. Embora essas intervenções tenham sido barradas, principalmente por força do decreto de tombamento, a área passou por um intenso processo de modificação, principalmente da vegetação nativa que circundava a ermida e que lhe garantia um aspecto bucólico e meditativo.

Recentemente, a Ermida Dom Bosco foi incorporada à área do Parque Ecológico Dom Bosco, criado pela Lei Complementar $n^{0} 219$, de 08/06/99, e implantado para assegurar a proteção do monumento. 
Em 30 de agosto de 1883, Dom Bosco (santo italiano, nascido em 1815 e fundador da Ordem dos Salesianos) teve um de seus famosos sonhos. Alguns trechos do que ele relatou:

Entre os paralelos de $15^{\circ}$ e $20^{\circ}$ havia uma depressão bastante larga e comprida, partindo de um ponto onde se formava um lago. Então, repetidamente, uma voz assim falou: “ quando vierem escavar as minas ocultas, no meio destas montanhas, surgirá aqui a terra prometida, vertendo leite e mel. Será uma riqueza inconcebível...”

Notas adicionais:

Em seu livro "Brasília - Memória da Construção”, Tamanini diz que a referência a “uma grande civilização” (ou sequer a palavra “civilização”) não aparece em qualquer parte do relato do sonho. Mas a expressão teria passado a fazer parte da "versão oficial” do sonho, e a ela "passariam a se reportar expressamente, com pequenas variações, todos quanto ao sonho já se referiram, ligando-o à construção de Brasília”.

A distorção das palavras de Dom Bosco chega a verdadeiros exageros, diz-se que Dom Bosco previu que “a capital do Brasil seria construída entre os paralelos 15 e 20”. Ou seja, de “terra prometida” se passou a “civilização” e daí a “capital do Brasil”

3.3. O Pólo 3, abrange uma área de $578.592 \mathrm{~m}^{2}$ entre o Clube da Imprensa e o Bosque dos Leões, próximo ao Palácio da Alvorada. Possui lotes para hotéis, entre eles o Brasília Palace. Caracteriza-se como Pólo Cultural, onde existe o Museu de Arte de Brasília e a Concha Acústica que associados ao Pavilhão Bienal e Arte, constituem a Praça das Artes, comércios, bares, restaurantes, cinemas e marinas instaladas.

A ousada iniciativa batizada de Projeto Orla, é recebida com louvores pelos brasilienses, visitantes que contemplam e participam de atividades na Orla do Lago Paranoá e iniciativa pública e privada, que enxerga ali um filão em termos de investimentos.

O Pólo 3, inaugurado numa área próxima ao Palácio da Alvorada, residência Oficial do Presidente da República, traz uma significativa mudança na rotina de uma população acostumada a aproveitar os finais de semana em casa, shoppings ou clubes sociais. 
No calçadão de 650 metros de extensão construído ao lado da Concha Acústica de Brasília, estão em funcionamento quiosques semelhantes aos que existem em cidades litorâneas, Lá os brasilienses e turistas dispõem de uma área ao ar livre onde podem caminhar, namorar, se reunir com os amigos e acompanhar o movimento de embarcações do Lago Paranoá.

3.4. Pólo 6 - Centro de Lazer Beira Lago, numa área de $20.000 \mathrm{~m}^{2}$, junto ao acesso a Terceira Ponte do Lago Sul, localiza-se um centro comercial e de diversões, com bares, restaurantes, fast-foods, cinemas, comércio, lojas de conveniência, alojamentos, quadra de tênis, campos de futebol, ginásio poliesportivo, ginásio exclusivo para patinação, piscinas olímpicas, serviço médico, sauna, salão de beleza, boutique e biblioteca, espaços para arte e cultura e uma marina pública, academias, escola de iniciação esportiva de futebol, vôlei, natação. Tênis, e futebol de mesa.

São realizados campeonatos nacionais e internacionais com a duração de 15 a 20 dias, sendo os mais praticados: patinação artística, regata (windsurf), futebol de campo, futebol de salão, voleibol, futevôlei, tênis e futebol de mesa.

Existe uma diversidade de embarcações monotipos, são barcos pequenos, dings, optimist, rolequete classe oceânico, barco à vela, fórmula Brasília, Fortilho, Delta Fast, entre outros.

São realizados eventos sociais anualmente, como a festa do atleta que ocorre dia 11 de dezembro, o aniversário da AABB, apresentação da Banda Satisfaction, bailes, almoços, jantares dançantes, e confraternizações. O preço da alimentação é variado de acordo com o mercado.

Durante a realização dos campeonatos, a demanda de público para Brasília e por estes motivos a AABB - Associação Atlética Banco do Brasil, mantém convênio com a Rede Hoteleira do Distrito Federal, para a hospedagem do público envolvido nos campeonatos e eventos. 
3.5 Pólo 11 - Pontão do Lago Sul, área de $110.000 \mathrm{~m}^{2}$ já consagrada como área de lazer com decoração ambiental natural e artificial: jardins, cachoeiras, paisagem ornamentada, com vista para o Píer 21 e áreas residenciais, com restaurantes, lojas de surf, chopperia, bares e loja de antiguidades. No Pontão Fashion é realizado mensalmente uma feira de artesanato.

A implantação do Projeto do Pontão do Lago Sul fornece a população de Brasília uma infra-estrutura digna de seu potencial socioeconômico e turístico.

O Pontão do Lago Sul atrai uma gama variada de pessoas que se deslocam para o Empreendimento em busca das mais variadas atividades entre esportes, lazer e entretenimento.

O empreendimento se transforma na mais nova opção de lazer para famílias inteiras que aproveitam todas as dependências do local por um período prolongado, que oferece opções de lazer.

É freqüentado por grupos de executivos em almoços e jantares de negócios, atrai jovens e adolescentes para a prática de esportes em suas instalações, proprietários de barcos e lanchas utilizam o espaço em conjunto com o lazer náutico, além do atrativo turístico local que gera a nobreza de seus espaços e a magnitude de suas paisagens.

O Pontão do Lago Sul representa uma alternativa como área de lazer, já que são poucos os espaços públicos com esse perfil em que a população de Brasília tem livre acesso. Esse atrativo se intensifica principalmente nos finais de semana e feriados, onde a procura por áreas desse tipo pela população em geral naturalmente se amplia.

Atualmente na orla do Lago Paranoá, são desenvolvidas atividades de lazer e recreação que representam um grande potencial para o desenvolvimento sócio-cultural. Restringem-se a campeonatos de barco a vela, passeios de lancha, remo, Jet Ski, Ski aquático, atletismo, triathlon, campeonato de skate e shows musicais.

O Lago Paranoá hoje encontra-se “privatizado” já que a sua orla está dividida entre os empreendimentos particulares, residências e clubes de acesso restrito aos associados ou proprietários.

Como atração gastronômica oferece uma nova opção de restaurantes, bares e chopperia, implantados em um local favorecido pela paisagem e pelo visual urbano. 
O Pontão do Lago Sul é parte da iniciativa do Governo do Distrito Federal em revitalizar espaços e inserir equipamentos voltados para o lazer da população e o desenvolvimento do turismo em Brasília.Com esses objetivos, o Poder Público do Distrito Federal, lançou o Projeto Orla, onde o Projeto do Pontão do Lago Sul é parte integrante e que visa dotar às margens do Lago Paranoá, um dos mais importantes elementos naturais de Brasília, de uma série de equipamentos públicos e provados, de forma a atender essa meta, possibilitando à iniciativa Privada a oportunidade para instalação de equipamentos de lazer, esportes, comércio de bens e prestação de serviços, que possam servir a população local, a dos municípios da região e, ao mesmo tempo, se constituir em pólo indutor do turismo nacional.

A área escolhida para a implantação do Projeto do Pontão do Lago Sul representa uma das poucas áreas remanescentes às margens do Lago Paranoá onde ainda é possível a criação de equipamentos de uso público, permitindo que a população tenha acesso irrestrito ao lazer junto ao lago.

3.6. Praia dos Orixás - “Prainha”, localizada junto a ponte Costa e Silva, região administrativa de Brasília, abrange atividades humanas como a prática da cultura afrobrasileira, local para banhistas, uma ponte rústica de madeira construída no interior do Lago Paranoá, que aproxima os visitantes dos desportistas de modo que inclui produtos do sentir, do pensar e do agir humano.

O texto analisa dados sobre elementos constitutivos do espaço turístico de Brasília e faz uma reflexão sobre o uso da imagem-Brasília: Cidade Monumento Patrimônio Cultural da Humanidade, tombada pela UNESCO e propõe como alternativa de marketing do lugar um roteiro turístico no segmento cultural.

Segundo (Barreto,1995, p.21) “A necessidade de segmentar o mercado e conhecer as motivações dos turistas fazem com que algumas modalidades turísticas englobem ou excluam outras, justamente para que se tenham novos nichos de mercado, movimentando assim, mais atividades produtivas”. A noção moderna de patrimônio cultural não se restringe à arquitetura a despeito da indiscutível presença das edificações mas também outros atrativos turísticos para proporcionar maior número de visitantes e basear-se no 
espírito de cidadania e consolidar assim o status de lugar, nação a capital de todos os brasileiros.

3.7. A Prainha do Lago Norte, que por algum tempo foi denominada de "Piscinão do Lago Norte”, participa como elemento do cenário paisagístico e urbano, que envolve o Plano Piloto de Brasília. Suas areias avançam 20 a 30 metros lago a dentro, proporcionando aos banhistas diversão e lazer.

Nas considerações a respeito da oferta turística, a geografia assume papel importante como elemento de identificação e de caracterização na definição da própria natureza do produto específico que se explícita em conformidade com a divisão política do espaço e em seus recursos naturais, além da própria densidade demográfica de tal ocupação permanente. Enfim, o espaço geográfico é o elemento materializador de determinado potencial turístico e sua configuração, física. É a bandeja dourada das oferendas que os empresários de turismo colocam a disposição dos desejos e das preferências de seus clientes.

Dentre as diversas características físicas e os vários elementos ornamentais das paisagens consideradas ofertas turísticas naturais, por suas inconfundíveis propriedades, destacam-se as seguintes: locais que propiciem possibilidades de visão panorâmica expressiva, nascentes de água dentre outros. Todos e cada um desses elementos assumem incomparável valor estético quando emoldurados pelo equilibrado dimensionamento do solo, de que a beleza sempre sobressai na contrastação com o horizonte, cuja finalidade maior parece ser a de suscitar no homem o fascínio pela natureza, que simula limitar.

O turista, como qualquer outra pessoa, exerce a ambivalente e concomitante função de agente aculturador e de elemento suscetível de sensibilização por culturas outras que a sua própria. Assim, pelo próprio desejo ou pela necessidade de participar de ambientes e sociedades diferentes dos que lhe são próprios, ele se dispõe a interferir e a integrar-se, em um processo cultural, como elemento ativo e passivo de influência. 


\section{CONCLUSÃO}

Após os estudos e pesquisas realizados para a feitura desta monografia, além das informações obtidas de pioneiros de Brasília e diante dos diversos textos que subsidiaram o nosso trabalho, e ainda, com base na experiência adquirida ao longo de 20 anos na área, podemos chegar às seguintes conclusões, ainda que provisórias:

Brasília, desde os primórdios de sua construção, sempre exerceu, farto fascínio sobre os turistas, independentemente das condições econômicas, sociais e culturais, para a sua visitação.

Por tratar-se de uma cidade menina, Brasília esteve e continua carente de uma política voltada para o desenvolvimento turístico e, por conseguinte, desprezada para a ampliação do fluxo de turistas.

Com a criação e implantação da secretaria de Turismo, pelo Governo do Distrito Federal, observa-se um aumento do crescimento turístico da cidade, aos poucos, avança na criação e modernização dos meios físicos, materiais e humanos, com a participação, cada vez maior dos setores público e privado.

Dentre outros exemplos, pode-se mencionar os investimentos, já aplicados, no Projeto Orla, como fator que vai contribuindo para o turismo em Brasília.

Existem atrativos de grande importância como a implantação do Centro de Lazer Beira Lago - AABB, com a prática de campeonatos internacionais, escola de iniciação poli-esportiva, realização de eventos, desenvolvimento do turismo náutico com a realização de competições em várias categorias de embarcações.

No Pontão do Lago Sul, vale ressaltar a contemplação da sua beleza, e a sua dimensão comercial elástica; com restaurantes, bares, lojas de antigüidades, feira de artesanato, lojas de surf, passeios de barcos e realização de campeonatos esportivos.

O Pier 21 se destaca com o desenvolvimento de um centro de lazer e entretenimento com restaurantes, cinemas, academias e boates.

O Projeto Orla atraiu a instalação de redes de hotéis, ampliando os leitos e trazendo a Brasília relevante posicionamento no mercado hoteleiro, entre outros. 
Além destas conclusões, podemos facilmente chegar à outras que apontam algumas necessidades, a saber:

Ampliação da oferta de produtos/serviços tais como viabilizar parcerias públicas e privadas visando investimentos em equipamentos para eventos, investir em serviços de recepção, informação e de qualidade para o turista, preservar, conservar e revitalizar os atrativos turísticos já existentes no Projeto Orla para flexibilizar a sua expansão, implementação de equipamentos mais diversificados na orla do Lago Paranoá, onde poderse-ia promover um contato mais aberto entre brasilienses e turistas, capaz de permitir que estes sintam o calor humano que possuímos.

Cursos de capacitação em atendimento ao turista para todos que, de algum modo, tenham contatos com estes, devendo, aí, estarem incluídos desde o empresário até o vendedor de picolé e de água-de-côco.

Para a população de baixa renda, deve haver uma promoção da iniciativa pública em parceria com a iniciativa privada, para o desenvolvimento de atividades turísticas que levem em conta os aspectos econômicos, sócio-culturais e ambientais do Distrito Federal, prover um benefício expressivo para o crescimento da atividade de turismo e resultados para o Estado. O modelo de desenvolvimento é a base na exploração equilibrada da comunidade de modo a atender a satisfação das necessidades e do bem estar social. A prática de turismo somente para a elite restringe o crescimento da atividade. 
ANEXO 
ANEXO

A Lenda do Lago 


\section{A Lenda do Lago}

Tu que resides nas quadras do lago, ou que nele pescas, ou que nele velejas, ou simplesmente o transpões no teu cotidiano, não olhes Paranoá indiferentemente.

Há os que pensam que o Lago é obra do engenho humano, um represamento de águas por uma barragem que tem o seu nome, Não, não e assim. Essas águas nasceram do encantamento de um índio da tribo dos goiases que aqui viveu, finalmente vitimado pelas duvidas do seu coração

Se prestares atenção, no silêncio das noites cálidas ou na placidez das horas matutinas, quando todo ele é um grande espelho refletindo a vegetação das margens ou barcos solitários, - ouvirás murmúrios, leves suspiros, quase um lamento.

É o espírito de Paranoá contando sua desdita às tilápias.

Conhecerás agora sua lenda...

Isso faz muito tempo, muito tempo mesmo, antes que o primeiro bandeirante pisasse por estas plagas.

Os goiases já não eram muitos, porque grande parte deles migrara para lugares distantes, em busca de florestas densas e continuadas. Não era falta de caça, não. Caça havia. Muito veado mateiro, muita capivara, muita anta.

Contavam que o pai de Paranoá, que nem ligava muito o curumin, havia morrido picado por uma cascavel, que nenhuma erva e nem o subandara puderam salvar. A mãe, tomada de amores por outro índio, fora embora também, deixando o menino com o cacique que, por sinal, tinha grande afeição por ele.

Pois foi numa debandada grande de goiases para terras distantes que o cacique, à beira do fogo, ficou cismado sobre o destino de Paranoá. Cismado, cismado. O luar derramava-se sobre a taba quando ele recolheu-se à quiçaba, cismado. Sempre cismado.

Pela alvorada, levantou-se, olhando ao redor, o semblante como que desanuviado de preocupações, parecendo ter recebido durante a noite a resposta para o que o inquietava, Paranoá, ali por perto, brincava, descuidado, com um jaboti que, na véspera, havia aprisionado. 
O cacique deixou que a manhã avançasse e, chamando o menino, foram a um lugar ermo para conversar a sós. Foi longa e cuidadosa a conversa, porque o chefe sabia que o curumin ainda não podia entender certas coisas.

O menino escutava, atento, enquanto o cacique falava:

“Nossa gente vem de remotos tempos e de longínquas paragens. Já fomos muitos e em vão tenho pedido que fiquem aqui, mas, pouco a pouco, estão indo embora quando eu queria que a nossa tribo se multiplicasse nestas terras dos seus avoengos. Aconteça, porém, o que acontecer, tu, Paranoá, permanecerás e serás o continuados da nossa raça. Tu crescerás. Entretanto, quando chegar a hora de tomares mulher, não procurarás nenhuma da nossa tribo, ainda que até lá alguma permaneça entre nós. Tu renovarás em sangue a presença dos goiases aqui no planalto do Pindorama.

Tupã visitou-me nessa noite para determinar teu destino. Ele te trará, um dia, a mulher que viverá contigo e te dará grande descendência. Ela virá à frente e, depois dela, outros chegarão de muitas procedências. Ouvirás, um dia, como que um tremor de terra e o eco de estranhos machados golpeando a mata. Ela, a mulher que Tupã te destinou, cuidará da abertura de caipés para todas as direções e ligará distâncias para que silvícolas de todos os continentes venham vê-la.

Tu, Paranoá, contudo, terás, de dar provas do teu merecimento, Jamais demonstrarás impaciência na tua espera. Adestrarás tua flecha, na caça das melhores presas e saberás que frutos lhe trarás sempre para regalá-la. Tornar-te-ás exímio em tudo, um guerreiro de estirpe para que a tua amada se orgulhe de ti e aspire com ansiedade a tua volta a cada partida. Esperarás, portanto. Não importa o tempo. Jamais afastarás teu pensamento dessa mulher e nunca te desviarás em sentimento por outra, por mais que te seduza ou arme ardis para conquistar-te.”

Paranoá jamais esqueceria a inesperada fala do cacique, Entendera o sentido de tudo, mas muito do que ouvira confundia-se no seu desconhecimento das coisas.

O tempo foi passando, longo, arrastado. Da tribo quase ninguém mais restava e Paranoá, agora adolescente, despertou certa manhã sem a presença do próprio cacique. 
Viu-se só, ao mesmo tempo em que, olhando-se num espelho d'água, observou que seu corpo se transformava. Não era mais menino, Era um homem, E lembrou-se das advertências do cacique.

Quanto tempo passaria à espera? Como venceria a solidão que se anunciava em tudo. Agravando-se no silêncio dos crepúsculos quando o horizonte, pelo lado do poente, se fazia escarlate como pitanga madura e os jacus-ciganos partiam em revoada, eles que viviam em bandos e em bandos se recolhiam?

Os dias se repetiam, monótonos, mas o índio superava qualquer enfado porque sabia que Tupã lia o pensamento dos homens, Só uma vez irritou-se, mas só um instante, um quase nada. Foi quando observava um belo peque, lembrando-se que nunca utilizara seu pigmento como faziam os índios de sua tribo para enfeitar-se e, de repente, pareceu-lhe ver o vulto de Jurupari, rindo dele atrás de um tronco de sucupira. Sufocou, porém, a contrariedade, distraindo-se com a beleza de um ipê, onde pousara uma arara azul, compondo-se, harmoniosa, dentre a floração amarela.

O riso sarcástico do Jurupari, porém, sempre prenunciava coisas ruins. Naquela noite, notou que Jaci, a lua, parecia dirigir toda sua luz sobre o seu corpo. Ungia-o, acariciava-o. O índio repeliu-a refugiando-se sob a ramagem densa para que ela não o visse, Era a primeira tentação que repudiava. Lembrava-se das advertências do cacique. Não podia render-se. Jaci, porém, repetiria muitas e muitas vezes aquele aceno.

Paranoá ignorava o quanto a lua o queria, condoída, ao demais, da sua solidão. $O$ sofrimento da espera fazia-se agora maior a casa ciclo lunar, porque era quando Jaci mais o atormentava, perseguindo-o por toda parte, até que a manhã despontasse para sua libertação.

Quanto tempo passaria assim! Quanto tempo! Paranoá já agora desconhecia a própria idade. Via-se apenas forte, másculo, ágil, destro na caça, hábil no manejo da flecha e maneiroso no cavar pirogas que singrava as águas na pesca abundante. Nada, porém, compensava aquela solidão que só não o desesperava de um todo porque Tupã nada prometia sem cumprir. Era esperar e esperar, que a prometida chegaria para que ele cumprisse sua missão de retomar com sangue novo a presença dos goiases em terras planaltinas.

O índio ficava a imaginar como seria ela. Lembrava-se das mulheres da tribo, Recordava-se das feições de algumas delas, brônzeas, olhos amendoados, uns cabelos de 
piaçaba. Não, a dele não seria assim; seria diferente, pois lhe dissera o cacique que ela seria diferente.

Foi assim, depois de tanto olhar distâncias, mãos em pala, que o sol perturbavam de tanto colar o ouvido ao chão, à escuta de um ruído denunciador, que Paranoá, certa tarde, foi refrescar-se num caiabu. Ali, á sombra, ouviu com que o ribombo de um trovão. Não podia ser. Os longos meses da chuva já haviam passado. Prestou atenção: os ruídos repetiam-se, mais fortes. A mata estremecia, Estremecia o cerrado. Parecia que muitos machados num misterioso ritmo, abatiam o arvoredos ao som de mil inúbias.

Será? - indagou-se o guerreiro. Olhou até aonde seu olhar alcançava: de um clarão apoteórico no horizonte emergia uma figura de mulher, envolta em esplendores, adornada de bizarros enfeites, A mulher veio vindo, como que descendo do infinito, até aproximar-se de Paranoá.

O índio sufocava-se de emoção, extasiado ante tanta beleza. Claro que ela não era como as mulheres da tribo. Além de tudo, alada, Asas tênues, diáfanas, emolduravam a figura, como uma divindade.

Impulsionado no seu deslumbramento, Paranoá correu para ela. Querioa cingi-la, mas conteve-se:

- És tu a anunciada de Tupã?

- Sou, Paranoá. Tu agora não viverás mais só. Eu sou Brasília!

O índio emudeceu.

A longa espera, a ansiedade de tanto tempo, o mistério daquela aparição, o fulgor daquela criatura o paralisavam, atropelando-lhe a mente. Queria enlaça-la, porém estava como que enfeitiçado, como que tonto de cauim, pregado ao solo.

Mas era tempo de Jaci e Jaci espreitava aquele encontro, aquela cena na tarde que esmorecia. Ela amava Paranoá. Sem correspondência embora, acalentara-o em silêncio, noite após noite, na longa solidão. E agora? Agora a outra viera. Tudo estava consumado e morria a última esperança. Restava-Ihe contudo um gesto desesperado e derradeiro. Ela 
não o conquistara quando estava só e agora o perdia para sempre. Postou-se então, na sua aflição, entre Paranoá e Brasília. Queria refletir-se pela última vez nos olhos go guerreiro e depois partir, esmagada no seu amor impossível.

O olhar da lua ofuscou Paranoá; ofuscava mesmo o esplendor de Brasília. Eletrizado, o índio fixou-se no olhar da lua e, pela primeira vez, contemplou sua meiguice, a suavidade da sua luz, envolvente e penetrante. No seu coração explodia um sentimento longamente represado. E depreendeu, atônito, que, sem querer, amava Jaci.

No espírito do guerreiro, um turbilhão de incertezas. Mudo, petrificado, olhava a lua, olhava Brasília, olhava Brasília, olhava a lua. Os momentos iniciais daquelas emoções transformavam-se num pesadelo. E um silêncio seguiu-se, pesado, interminável.

Então o céu rasgou-se e uma voz ouviu-se, grave, sentenciosa. Era Tupã, irritado:

- Por que procedes assim, Paranoá? Por que entra em dúvida o teu coração? Não te abstou acaso o tempo da espera para a tua preparação? Ah, não foste digno da mulher que te prometi e vou castigar-te, transformando-te num lago, de braços sempre abertos, sem jamais alcançar aquela por quem tanto esperaste.

Do corpo de Paranoá foram descendo bagas diluindo-se todo, ante o olhar indiferente de Brasília e o olhar desesperado de Jaci. Pouco a pouco, do que era o corpo másculo do índio só restava uma poça d'água que foi se estendendo e conformando-se num amplo lençol ramificado como braços clamando.

Jaci, tomada de angústia e remorso, demandou o espaço, ocultando-se atrás de uma nuvem. Contemplava do alto, atormentada e chorosa, o seu amado transmudando-se num lago. 
Assim termina a lenda. Brasília permaneceu no Planalto, altiva e bela. Olha Paranoá apenas à distância, alheia ao seu destino, ,mas Jaci não esqueceria jamais o seu amor.

Nas noites de luar é ela que volta para ver o seu amado. Ela sabe que ele está ali, mas águas serenas das manhãs ridentes ou no ondular que o vento agita, embalando os barcos. Demora-se sobre o lago e, como a expungir-se de culpa, cobre de prata a sua superfície e inunda Brasília de luz.

E sempre que regressa, pela madrugada, chorando orvalho, vai mentido ás estrelas pastadas no seu caminho que assistiu, durante a noite, às núpcias de Paranoá e Brasília.

Texto de Guido Mondin

"Uma homenagem da comissão do Distrito Federal do Senado Federal pela passagem dos 25 anos de Brasília”. 
APÊNDICE 


\section{APÊNDICE}

\section{Entrevista 1}

Sr. Marcos Pompeu de Souza Brasil, Secretário Adjunto do Governo do Distrito Federal, e Secretario Executivo do Fórum Brasileiro de Secretários de Turismo 


\section{ENTREVISTA 01}

\section{Maria de Jesus}

Eu sou Maria de Jesus, estudo na UNB no Centro de Excelência em Turismo, no curso de especialização para professores e pesquisadores em Turismo e hospitalidade. Espero sua colaboração no sentido de responder algumas perguntas referentes ao turismo do Distrito Federal.

Na atual gestão qual a política de turismo do Governo do Distrito Federal para esse mandato?

\section{Marcos Pompeu}

O meu nome é Marcos Pompeu de Souza Brasil, Secretário Adjunto do Governo do Distrito Federal, e Secretario Executivo do Fórum Brasileiro de Secretários de Turismo; a minha formação acadêmica, eu sou Doutor em Direito, especializado em marketing (termos não identificados) em turismo. Antes da secretaria do turismo do Distrito Federal, ano passado eu fui Diretor Adjunto de economia e fomento da EMBRATUR, e assessor do ex-Ministro de Esporte e Turismo Caio Luiz de Carvalho; e antes de vir a Brasília eu atuei como Subsecretário de Turismo do estado do Ceará de 1995 a abril de 2002, nos dois últimos governos do Governado Tarso Gereisat, eu fui o Subsecretário fundador da Secretaria de Turismo do estado do Ceará. As experiências profissionais do turismo são essas. No governo do Ceará, no Governo Federal e agora no Distrito Federal.

\section{Marcos Pompeu}

O Governo do Distrito Federal, o Governador Joaquim Roriz, no inicio do seu quarto mandato, deu, está dando e dará uma prioridade muito especial e particular ao turismo, haja vista que o Governador reestruturou a Secretaria de Turismo do Distrito Federal. Ano passado o turismo do Distrito Federal era coordenado por uma agência de desenvolvimento do Turismo, a DETUR, e o fato do Governador Roriz ter reinstalado uma Secretaria de Estado e Turismo em si já representa, já demonstra o apoio e o prestigio que o governador quer dar à pasta do turismo. A partir daí convidou para assumir a pasta a Embaixatriz Lucia Flecha de Lima, que é uma pessoa de grande experiência e tem uma carreira 
diplomática de quarenta e cinco anos prestados ao país como Embaixatriz, esposa do Embaixador Paulo Tarso Flecha de Lima, que é um ícone da diplomacia brasileira; e com essa escolha o Governador trouxe também para o Distrito Federal uma personalidade internacional que tem uma experiência muito grande para coordenar as ações da pasta do turismo. A partir daí a Secretária Lúcia Flecha de Lima montou e uma boa equipe técnica. Hoje na sua equipe técnica nós temos nove integrantes da equipe direta da assessoria da Secretária que foram ex-integrantes da EMBRATUR, do Ministério do Turismo, portanto essas pessoas trazem uma experiência importante do ponto de vista técnico, e são esses sinais que nos dão a certeza de que o governador prioriza e priorizou o setor do turismo nessa atual administração.

\section{Maria de Jesus}

O planejamento viabiliza parcerias com (termo não identificado) privado visando investimentos e em equipamentos para eventos?

\section{Marcos Pompeu}

Certamente, em relação a equipamentos para eventos, um dos fatos mais importantes da atual gestão do turismo no Distrito Federal e uma das prioridades do Governo Roriz nesse atual mandato, é a reforma e ampliação do Centro de Convenções Ulysses Guimarães. O centro de convenções está em plena reforma e ampliação. Será construído ao lado do bloco existente, dois novos blocos, sendo o primeiro com um conjunto de auditórios onde o Auditório principal terá a capacidade de quatro mil e cem lugares, deverá ser o maior e mais bem equipado auditório do Brasil, e integrado a um conjunto de outros auditórios, e esse complexo de auditórios terá a disponibilidade de sete mil e cem acentos. Com certeza será um conjunto único no Brasil com essa capacidade de auditórios, e naturalmente sem falar nas instalações audiovisuais e todos os equipamentos necessários e modernos para atender a grandes eventos e congressos, e seminários que possam ser atraídos para a capital do Brasil.

Do outro lado do centro de convenções atualmente existente será construído um parque de exposições com capacidade para trezentos standes, então pode-se imaginar que quando a senhora fala no planejamento e particularmente em equipamentos para eventos, agora em 2004 até o primeiro semestre o governador entrega esse conjunto de auditórios. 
No segundo semestre de 2004 está previsto a conclusão da parte de exposições e da reforma do miolo já existente. Portanto, o ano de 2004 será um marco da entrada de Brasília e do Distrito Federal no setor de capitação e realização de grandes eventos internacionais dada a capacidade e a modernidade de que será o seu novo centro de convenções.

Em relação às parcerias públicas e privadas eu devo dizer que o turismo hoje só prospera ou avança a partir das parcerias. O governo, cada vez mais fica responsável pelas macro infra-estruturas, o planejamento estratégico, os planos diretores, as infra-estruturas de obras, como o centro de convenções, rodovias, aeroportos, saneamento; esse é o papel cada vez mais do governo, mas quem opera o turismo, quem constrói os equipamentos do turismo são as iniciativas privadas. Então os hotéis, as agencias de viagens, as transportadoras turísticas, enfim, toda a operação turística é feita por empresas privadas. E ao governo cabe um pouco da regulamentação, um pouco da infra-estrutura, as macro infra-estruturas e a macro regulamentação são papeis do governo. A operação do turismo é sempre um papel privado, e portanto, quando há a parceria entre os órgãos públicos e entre as empresas privadas, o turismo e desenvolve; quanto maior a parceria, mais rápido o turismo se desenvolve.

\section{Maria de Jesus}

Está incluso nos planos de desenvolvimento do turismo para o futuro uma política eficaz de educação e treinamento de forma integrada envolvendo todos os elos da cadeia produtiva?

\section{Marcos Pompeu}

Essa talvez seja a questão primordial do turismo, porque o turismo essencialmente passa por uma prestação de serviço de qualidade, o que encanta o turista, o que faz o turista ser fiel, além das belezas naturais, da infra-estruturas físicas e os equipamentos que o destino possa oferecer, sempre haverá o componente humano, porque o turista está sempre interagindo com os serviços que são prestados por pessoas; desde o motorista do táxi, ao recepcionista do hotel, à camareira, ao garçom, ao maitre, ao agente de viagem, enfim a grande cadeia produtiva do turismo, e aí entram o comércio, as lojas, o artesanato, a cultura. Ou seja, o turista busca a interação com as culturas dos destinos onde ele visita, 
quer ele viaje a trabalho, ou a lazer, mas ele sempre está interagindo com pessoas, e o componente do treinamento, da capacitação profissional talvez seja o grande diferencial que o turismo pode oferecer. Portanto a Secretária no seu plano da Secretaria de Turismo do Distrito Federal tem um interesse especial pela parte de capacitação, de certificação para que nós possamos ser uma referencia nacional e internacional em termos de treinamento e qualidade de atendimentos. Isso é feito também a partir de parcerias, porque todos sabem que o SEBRAE, o SENAC, o Fundo de Amparo ao Trabalhador, existem diversos organismos e programas a níveis Federal, estadual e municipal que geram uma possibilidade de capacitação de treinamento muito grande. Então cabe aos secretários dos estados, cabe aos governos saber priorizar e articular bem essa oferta de treinamento para que haja de fato uma boa padronização de serviços, e que o turismo se qualifique e se diferencie pela excelência dos seus serviços.

\section{Maria de Jesus}

Quais são as estratégias de marketing turístico para fomentar o turismo do Distrito Federal?

\section{Marcos Pompeu}

A Secretária Lúcia Flecha de Lima no seu organograma da sua equipe tem duas subsecretarias. A Secretária do Turismo do Distrito Federal nessa nova fase que tem tido muito apoio, muita determinação da Secretária e do Governador, a secretaria está estruturada com duas subsecretarias, uma de marketing e eventos, e a outra de planejamento e avaliação. Isso quer dizer que na prioridade do trabalho da secretaria, de um lado está o planejamento onde se desenvolve a política e o planejamento estratégico do turismo, os programas, as ações e os planos; e esses programas normalmente estão em consonância e metas dos programas do Ministério do Turismo do Governo Federal. E de um outro lado existe a área de marketing e eventos, tendo em vista que o marketing a partir da pesquisa, da formatação de produtos, da qualificação de produtos, e da promoção, é um dos elementos mais importantes do turismo, porque o marketing não cuida só da promoção, ele cuida a principio, da pesquisa, da formatação de produto, da qualificação do produto, da distribuição do produto e da promoção. E essa subsecretaria aqui conosco é uma subsecretaria de marketing e eventos, aí voltamos àquela pergunta anterior, da 
prioridade de eventos e do que será o Centro de Convenções de Brasília como uma referencia internacional para atrair um calendário muito rico de eventos nacionais e internacionais. Sabendo nós, estudiosos de turismo, que o turismo de eventos é o turismo que mais gera recursos para o destino, que mais ocupa a cadeia produtiva, e que portanto é o seguimento turístico que mais gera divisas e empregos para os estados.

\section{Maria de Jesus}

O plano prevê um sistema de gestão, informação e pesquisa para o setor turístico?

\section{Marcos Pompeu}

Esse é um outro ponto fundamental, e aqui aproveito para cumprimentá-la pelas perguntas que estão muito bem enquadradas dentro do que o turismo precisa estar atento, e do que nós precisamos também prestar conta do que estamos fazendo.

Uma questão fundamental, e que o próprio Ministro do Turismo, a EMBRATUR têm declarado aqui, que precisamos trabalhar intensamente é a questão da informação. O nosso banco de dados, do Brasil em termos de turismo, precisa ser melhor trabalhado no sentido de que as estatísticas nem sempre coincidem, quer dizer, os números da EMBRATUR as vezes divergem dos números das secretarias estaduais, ou da INFRAERO. Então é preciso se implantar um sistema integrado de pesquisa e de informação, e que dê ao turismo brasileiro, a partir das informações bem disponibilizadas, uma plataforma de planejamento e de ação que dê segurança, não só para os órgãos públicos que estão planejando e investindo e procurando gera as infra-estruturas adequadas, mas principalmente ao setor privado que par operar o turismo precisa ter informações do fluxo e do que o turista quer, de onde ele está vindo, do que ele precisa. Portanto, esse sistema de informações e pesquisas é a base de tudo. A minha especialização acadêmica é em marketing e eu tive a oportunidade de lecionar a disciplina em uma faculdade em Fortaleza durante três anos, e o marketing começa justamente na pesquisa, não se pode desenvolver um produto ou um serviço e colocá-lo na prateleira se nós não sabemos onde está o nosso cliente e o que ele deseja, por isso, a pesquisa e o sistema de informação nacional de informações turísticas é uma meta que o Ministério do Turismo e a EMBRATUR e as secretarias estaduais estão buscando com intensidade no sentido de que 
se possa ter um sistema integrado de informações, e que esse sistema possa subsidiar todo o planejamento estratégico, tanto da área pública quanto da área privada.

\section{Maria de Jesus}

Existe algum evento em evidência para a promoção do turismo (termo não identificado) em cada local?

\section{Marcos Pompeu}

Existem vários, eu devo dizer que Brasília tem uma vocação natural para sediar os grandes eventos do país, e também os grandes eventos internacionais que venham ao país, por quê? Porque aqui está a capital de todos os brasileiros, aqui está o Governo Federal, aqui estão o Presidente da República, os Ministros de Estado, aqui estão as presidências de diversas empresas nacionais e internacionais, aqui estão os embaixadores que representam todos os países que mantêm relações diplomáticas com o Brasil. Portanto qualquer evento que se realize em Brasília, seja em qualquer especialidade que esse evento diga respeito, ele em se realizando em Brasília, o evento tem a possibilidade de atrair essas personalidades internacionais e nacionais, empresários ou representantes dos governos ligados àquela especialidade. Portanto, Brasília tem uma vocação muito forte para ser um centro de excelência na realização de eventos no Brasil.

A senhora me pergunta se existe algum evento especial, eu posso dizer que existem na verdade no calendário eventos que estamos trabalhando, eventos esses muito especiais. Esse ano tivemos um evento que marcou aqui na história de Brasília, que foi Brasília Music Festival, que foi um evento internacional que colocou Brasília no circuito de eventos musicais internacionais, que a pouco tempo só se imaginava ter no eixo Rio de Janeiro e São Paulo. E Brasília cediou com muito sucesso um grande festival de música com artistas de renome internacional. Portanto esse evento vai virar seqüência e nos coloca no roteiro importante.

No ponto de vista dos esportes, temos um belo autódromo, temos um ginásio com uma estrutura esportiva capaz de sediar eventos esportivos de toda natureza. Do ponto de vista dos eventos culturais nós temos talvez um dos teatros mais bonito do Brasil, o Teatro

Nacional; temos exposições e concertos de operas, Brasília está muito bem equipada. E 
com o centro de convenções reformado nós teremos grandes congressos importantes. Falase em cediarmos aqui um Fórum Mundial de Turismo com participantes de todo mundo, isso em 2006. Em linhas gerais podemos dizer que o que se pensar em eventos podemos pensar em Brasília porque com certeza a partir dessa reforma do centro de convenções teremos condições de sediar todo tipo de evento. E me lembrando também, não posso deixar de passar essa oportunidade de dizer que nos eventos náuticos o nosso lago Paranoá já é uma referência, porque temos tido aqui campeonatos de vela, de várias modalidades vela, e que portanto o lago se apresenta também como um ambiente muito especial para os eventos náuticos.

\section{Maria de Jesus}

Como estamos iniciando uma nova gestão, lhe pergunto, há parceria com a iniciativa pública e privada para o desenvolvimento do turismo no Distrito Federal?

\section{Marcos Pompeu}

Eu continuar o que já comentamos em uma pergunta anterior. Essa questão da parceria é fundamental, os governos têm cada vez mais como eu já disse e vou repetir, o compromisso do governo sempre será com as macro infra-estruturas, físicas e humanas, e um pouco ainda com a promoção. Agora, a parceria com o setor privado é muito importante. Primeiro eu gostaria de falar que a parceria entre os setores públicos, porque nós temos que ter uma parceria muito estreita com o Ministério do Turismo, ele planeja a política nacional do turismo, e felizmente o Ministério do Turismo está construindo essa política de turismo, e lançou o plano nacional de turismo com uma ampla participação dos secretários estaduais, no Conselho Nacional do Turismo e da sociedade brasiliense. Então o Plano Nacional de Turismo que foi lançado no dia vinte e nove de abril pelo Presidente da República é um plano que precedeu a uma consulta muito grande, muito aberta, de todas as camadas da sociedade e todas as regiões do Brasil. A partir dos secretários de estados de turismo, dos conselhos e dos fóruns estaduais de turismo, e agregando as regiões brasileiras o Ministro ouviu e promoveu encontros para colher subsídios para o Plano Nacional de Turismo. Portanto, entendemos que essa integração nossa, do Distrito Federal com o Ministério do Turismo é uma política e estilo governo do atual Ministro do Turismo, como de fato era do Ministro anterior, e portanto o turismo tem essa característica de ser uma atividade onde essa integração é uma integração muito forte. 
Existe também uma integração importante que é da Secretaria de Turismo do Distrito Federal, com as outras secretarias do Distrito Federal, porque o turismo pode ser considerado como a indústria da viajem, e o turista é aquele viajante que pernoita fora do seu domicilio de origem. Seja qual for o motivo da viagem, a negócio ou a trabalho, a lazer, a tratamento de saúde, para visita de parentes, para participar de um evento, se cada um de nós pernoitar uma noite fora do nosso domicílio, nós somos considerados pela organização mundial do turismo, o turista. E o turista demanda que todos os serviços e produtos que o cidadão demanda também: transporte, alimentação, hospedagem, remédio, compras, lazer, cultura, então o turista é um cidadão que demanda várias atividades do estado. Portanto, a integração da Secretaria de Turismo com as outras secretarias do governo do Distrito Federal é uma integração muito importante. Com infra-estrutura, com desenvolvimento econômico, com obras, com saúde, com esporte, com cultura, porque não existem seguimentos estanques; hoje na administração moderna, as secretarias se comunicam de forma onde existem um grupo de secretarias que tenham atividades muito grandes, que no caso do turismo essa atividade é praticamente com todas as secretarias. Então falando da nossa integração com o Governo Federal e com o próprio governo do Distrito Federal, falamos também agora da integração do Distrito Federal com as outras secretarias de turismo do Brasil. E eu posso dizer que essa integração dos secretários dos estados de turismo é uma integração muito forte, e particularmente aqui no Centro Oeste a Secretária Lúcia Flecha de Lima coordenou a criação do grupo chamado Brasil Central, que reúne as Secretarias de Turismo do Distrito Federal, Goiás, Mato Grosso, Mato Grosso do Sul e Tocantins.

O que só se via a poucos anos no Nordeste brasileiro, agora se vê no Centro Oeste. O grupo de secretários da região se reuniram e criaram o Grupo Brasil Central, e na ultima edição da ABAVE, a maior feira de turismo da América Latina realizada no Rio de Janeiro agora de vinte e três a vinte e seis de outubro passado, o grupo Brasil Central se apresentou com um estande integrado e causou uma grande sensação nessa ultima edição da ABAVE. E finalmente falando da parceria com o setor Privado. O setor turístico em todo o mundo e no Brasil também está muito bem organizado, os hoteleiros estão organizados na Associação Brasileira da Indústria Hoteleira, ABNH, que aqui no Distrito Federal temos a ABNH-DF; os agentes de viajem se organizam na Associação Brasileira dos Agentes de Viajem; os transportadores se associam na sua associação de transporte; os bares e restaurantes também têm uma associação específica; os guias de turismo têm o sindicado 
dos guias de turismo; os bacharéis de turismo se associam em torno da Associação Brasileira dos Bacharéis de Turismo. Então nós entendemos assim as empresas organizadoras de congresso e por aí vai. Isso quer dizer que o setor privado, a cadeia produtiva do turismo está bem organizada, a partir das associações e dos sindicatos que representam essas diversas categorias profissionais. Tanto no Governo Federal quanto nos governos estaduais existe uma parceria dos governos com o chamado (termo não identificado) de turismo que são essas associações de sindicado que representam a cadeia produtiva. Portanto, a nível municipal, estadual e federal, essa parceria se dá de forma cada vez mais organizada, e com isso os resultados como eu disse anteriormente são resultados importantes no sentido do desenvolvimento e crescimento do setor.

\section{Maria de Jesus}

Marcos Pompeu, como você vê a posição de Brasília no cenário do turismo nacional e internacional?

\section{Marcos Pompeu}

Essa é uma pergunta que me dá a oportunidade de falar com muita alegria e com muito entusiasmo de que vejo Brasília e o Distrito Federal em uma posição única no cenário do turismo brasileiro, por quê? Aí eu vou comparar com as experiências que já tive. Quando me apresentei no início da entrevista eu informei que fui o subsecretário fundador da Secretaria de Turismo do estado do Ceará no período de 1995 a 2002, e nesse período o Nordeste cresceu muito, tínhamos no Ceará uma boa equipe técnica, um bom planejamento, o PRODETUR que é um programa de desenvolvimento de infra-estrutura, financiado pelo Banco Interamericano de Desenvolvimento, aconteceu nesse período. O centro de convenções de Fortaleza foi reformado nesse período, e o Ceará tinha uma atividade de promoção nacional e internacional muito forte. E o que eu estou vendo aqui no Distrito Federal e estou tendo a honra de participar com a Secretária Lúcia Flecha de Lima, nós temos aqui uma secretaria moderna com uma equipe técnica de reconhecida experiência, uma Secretária que é uma personalidade internacional, e uma pessoa que serviu como à diplomacia brasileira, com Embaixatriz por quarenta e cinco anos, portanto, tem todas as credenciais que um estado pode esperar de uma Secretária de estado de turismo. Tendo o apoio incondicional do Governador do Distrito Federal, e com isso oq nós estamos participando aqui no Distrito Federal. De uma secretaria moderna, de uma 
Secretária dinâmica e de uma boa equipe. E que mais, a reforma do Centro de Convenções, que teremos como referência internacional; se fala também, e a Secretária Lúcia e o Governador Roriz, tiveram duas vezes no Banco Interamericano de Desenvolvimento na perspectiva de que haja o Programa de Infra-Estrutura Turística PRODETUR JK, que vai ser o programa de infra-estrutura para a região Centro Oeste. O Distrito Federal apresenta uma capacidade de endividamento para dar conta a partir desse programa, que garante a execução do programa, e uma capacidade destacada se comparada com outros estados brasileiros. O aeroporto internacional de Brasília está passando por uma estação; Brasília tem essa vocação natural como a capital dos eventos do Brasil, como a capital do povo brasileiro, como o centro das decisões. Daqui nós temos diversos seguimentos que se desenvolvem com muita força, colocados no turismo rural, são mais de oitenta propriedades rurais em Brasília em condições de receber o turismo; o ecoturismo, turismo de aventura, aqui nós somos o portal natural de entrada de brasileiros e estrangeiros que queiram visitar a capital, patrimônio histórico e cultural da humanidade, uma cidade moderna, uma obra de arte. E daqui para partirem para o pantanal, e descerem para Foz do Iguaçu. Ou seja, queremos nos credenciar como o novo portão de entrada pra o ecoturismo, tanto da região Centro Oeste, quanto do Norte e Foz do Iguaçu.

Então o que eu vejo é que o Distrito Federal hoje, e a Secretaria de Turismo tem e reúne as condições técnicas, as condições políticas e as condições de recursos para promover o trabalho profissional, o trabalho competente do ponto de vista do planejamento, da promoção, da realização, da capitação de fluxo turístico, da capitação de investimentos. E eu não tenho dúvida que trabalhamos aqui com muito entusiasmo, e que haveremos de cumprir essa missão sobre a coordenação da Secretária Lúcia Flecha de Lima, e o entusiasmo aqui de toda equipe, eu vejo que o Distrito Federal estará ocupando uma posição de destaque em relação ao turismo brasileiro. Porque é o nosso momento, chegou a nossa vez; o Nordeste já é um destino consolidado, já tem um fluxo de vôos muito grande; o Sudeste, especialmente Rio de Janeiro e São Paulo também tem um fluxo já muito bem consolidado, mas chegou a vez do Centro Oeste, que é a bola da vez e que tem como seu portal de entrada, a capital do Brasil que é Brasília.

\section{Maria de Jesus}

Marcos Pompeu, muito obrigado por ter me recebido aqui, e estou muito satisfeita com suas respostas que integram plenamente a contextualização do meu projeto. 


\section{Marcos Pompeu}

Eu queria, Maria de Jesus, agradecer, eu, a oportunidade de falar, não só para você, mas acredito que essa entrevista possa ser ouvida por outras pessoas, colegas, alunos e professores; e dizer que a Secretaria de Turismo do Distrito Federal está a inteira disposição da universidade, e devo dizer que a parceria da secretaria com as academias e particularmente com a Universidade de Brasília é uma parceria também fundamental, a academia é que alimenta os governos, é que alimenta o setor privado com as pesquisas, com as inteligências, e que portanto essa relação com as universidades, com as faculdades é sempre um prazer, e uma oportunidade de falarmos um pouco do nosso trabalho. E estou entregando a você em mãos, um material da Secretaria de Turismo composto dos nossos novos folders, mapas e pastas que estão sendo distribuídas nos eventos nacionais e internacionais; já estão produzidos em quatro idiomas, português, espanhol, inglês e italiano, e portanto mostra um pouco desse novo momento do turismo no Distrito Federal. Um material que depois a senhora poderá analisar e apresentar a seus colegas, que é um material inédito aqui no Distrito Federal, que agora estará sendo disponibilizado a todos os profissionais de turismo brasileiros e estrangeiros. Muito obrigado 


\section{APÊNDICE}

\section{Entrevista 2}

Sr. Evander Wilson Marques Coordenador de Esporte da AABB - Associação Atlética Banco do Brasil 


\section{ENTREVISTA 02}

\section{Maria de Jesus}

Boa tarde, meu nome é Maria de Jesus, eu sou estudante do Centro de Excelência em Turismo da UNB, no curso de especialização para professores e pesquisadores em turismo e hospitalidades. Gostaria de saber se o senhor pode me conceder uma entrevista para a conclusão do meu projeto final.

\section{Evander Wilson Marques}

Sou coordenador de esporte da AABB, sou professor de Educação Física, e no que eu puder ser útil.

\section{Maria de Jesus}

Quais são os tipos de esportes realizados aqui na beira do lago Paranoá.

\section{Evander Wilson Marques}

Aqui na nossa associação nós temos futebol de campo, futebol de salão, voleibol masculino e feminino, futevôlei masculino e feminino, vôlei de areia masculino e feminino, natação, hidroginástica, esgrima, patinação, GRD que é a ginástica rítmica e desportiva, basquetebol, aikido, futebol feminino, futebol de mesa, e os esportes aquáticos na parte de náutica.

\section{Maria de Jesus}

São praticados campeonatos internacionais.

\section{Evander Wilson marques}


Às vezes sim, esses campeonatos realizados no momento, que estamos tendo, o campeonato Panamericano de Cadeirados de Tênis de Mesa, que é patrocinado pelo COG (Comitê Olímpico (termo não identificado). Temos atividade também a nível nacional, os Jogos da Juventude, e inicia agora também os Jogos Escolares Brasileiros, onde nós estaremos dando uma boa contribuição para a organização desses jogos.

\section{Maria de Jesus}

Quem organiza os campeonatos nacionais e internacionais?

\section{Evander Wilson Marques}

Esses campeonatos os quais eu falei agora, como os Jogos da Juventude e os Jogos Escolares Brasileiros são organizados pela Secretaria de Esportes do Distrito Federal, agora a maioria dos eventos ocorridos aqui são organizados pelas federações, confederações e o próprio Ministério do Esporte. Nós cuidamos mesmo é da parte da infraestrutura, e quando o campeonato é realizado por nós a organização é diretamente conosco.

\section{Maria de Jesus}

Durante a realização dos campeonatos nacionais e internacionais, há demanda de público para Brasília?

\section{Evander Wilson Marques}

Há sim, recebemos pessoas de diversos estados e países, inclusive como agora nos Jogos Paraolímpicos, são normalmente as pessoas envolvidas nos eventos e parentes, e uma grande parte de torcedores, de pessoas que gostam do esporte, e acompanham pela mídia e vêem nos ajudar.

\section{Maria de Jesus}

O clube possui também convênio com hotéis? 


\section{Evander Wilson Marques}

Sim, com boa parte da rede hoteleira do Distrito Federal.

\section{Maria de Jesus}

Quais os esportes que são mais praticados no Centro de Lazer da Beira do Lago?

\section{Evander Wilson Marques}

A nível de futebol, que é a "paixão nacional”, futebol de salão, futevôlei, vôlei de areia, tênis, futebol de mesa, sinuca e regatas. A parte de náutica nossa é muito divulgada, talvez por ser à beira do lago é o esporte que mais se encaixaria no perfil da orla.

\section{Maria de Jesus}

Quais dias são mais praticados esses esportes, nos finais de semana ou durante a semana?

\section{Evander Wilson Marques}

Praticamente são todos os dias, exceto às segundas-feiras que o clube fecha para limpeza e manutenção, mas de terça a domingo, de manhã a tarde e a noite geralmente tem escolinha funcionando, o esporte aqui é o nosso carro chefe.

\section{Maria de Jesus}

Normalmente qual é a duração dos torneios?

\section{Evander Wilson Marques}

Esses torneios a nível nacional ou internacional, geralmente são de quinze a vinte dias, agora os jogos internos que nós organizamos e dirigimos duram o ano todo, por exemplo, de abril até dezembro. 


\section{Maria de Jesus}

Há algum evento tradicional realizado anualmente?

\section{Evander Wilson Marques}

Há sim, nós temos a nossa Peça do Atleta que ocorre todo dia onze de dezembro, onde reunimos todos os atletas, desde os chupetinhas até os cinqüentões, que é a categoria máster onde temos atletas acima de cinqüenta anos. Tem o aniversario da AABB, festa Junina, Carnaval. E inicialmente nós fazemos um jantar para o show dos aposentados, em uma homenagem aos nossos aposentados que tanto fizeram pelo Banco do Brasil.

\section{Maria de Jesus}

O que o centro de lazer oferece como infra-estrutura?

\section{Evander Wilson Marques}

Nós temos aqui, podemos dizer, uma cidade. Temos restaurante, bares, alojamento, quadra de tênis, campo de futebol, ginásio poli-esportivos, ginásio para patinação, auditório, serviço médico, piscinas olímpicas, biblioteca, salão de beleza e boutique.

\section{Maria de Jesus}

Quais eventos sociais são realizados normalmente?

\section{Evander Wilson Marques}

São bailes, jantares dançantes, shows, churrascos, almoços, confraternizações diversas entre funcionários do banco, pessoas associadas independente do seu funcionalismo; apresentação do nosso coral, nós temos um coral, onde $90 \%$ dele é oriundo de funcionários do Banco do Brasil, que é a coqueluche aqui da nossa vice-presidência cultural. 


\section{Maria de Jesus}

O centro possui escolas iniciais poli-esportivas?

\section{Evander Wilson Marques}

Nós possuímos em praticamente todos os esportes, e funciona todos os dias da semana, alguns esportes funcionam aos sábados e domingos, mas a maioria é de terça a sexta-feira, para não prejudicar o associado, na hora que ele tem condições de vir ao clube, então as quadras e o ginásio tem que estar a disposição dele, mas normalmente as escolinhas vão de terça a sexta.

\section{Maria de Jesus}

Qual é o perfil dos sócios r dos visitantes.

\section{Evander Wilson Marques}

Em primeiro lugar vem o bancário, uma classe sofrida de muita luta, mas a maioria é de classe média alta, como os deputados e senadores, diplomatas, ministros, secretários de estado. A AABB é bem diversificada, nós temos aqui um conglomerado muito grande de pessoas de todas as classes sociais, e que convivem em uma harmonia muito grande.

\section{Maria de Jesus}

Quais são as categorias de embarcação existente?

\section{Evander Wilson Marques}

Sobre as embarcações eu não teria muito a dizer porque a minha área não é da parte náutica, mas temos barcos pequenos, (termos de barcos não compreendidos), classe oceânica, barco à vela, windsurf. E todos os barcos que competem na náutica nós temos aqui. 
Maria de Jesus

Muito obrigado senhor Evander. 


\section{CORPUS DOCUMENTAL}

\section{Documentos Escritos}

Revista Visão - 16 de maio de 1983.

Brasil. Projeto-Lei n 2924, de 20 de março de 2002. Dispõe sobre a criação do gerenciamento costeiro do Lago Paranoá.

Secretaria de Meio Ambiente e Recursos Hídricos - SEMARH. Disponível na Internet em: $<$ www.semarh.df.gov.br $>$. Acesso em 28 nov 2003.

Turístico, Cidades do Brasil, nov, 2003, Seção Cidades. Disponível na Internet em: <http://www.cidadesdobrasil.com.br/iniciativa/iniciativa01.htm.>, acesso em 28 nov 2003.

GODOY, Solange; CHAGAS, Mário. Patrimônio Cultural: as representações de memória nos museus. Anais do Museu Histórico Nacional, volume 28.

BARRETTO, Margarita. Manual de iniciação ao estudo do turismo. 9 ed. Campinas. Papirus, 2000. p.56.

Brasil. Projeto-Lei n 37, 2003. Institui o Programa de Peixamento do Lago Paranoá de Brasília - O pescandango.

CONFEDERAÇÃo NACIONAL DO COMÉRCIO, Programa Brasileiro da Atividade da Turística. Brasília, 2002.

FARIA, Dóris Santos de; Carneiro, Kátia Saraiva. Sustentabilidade ecológica no turismo. Brasília: Ed. Universidade de Brasília, 2001. p. 48 - 52

FUNATURA - Fundação pró-natureza. Plano de desenvolvimento sustentável do entorno do parque nacional Grande Sertão Veredas/MG. Brasília, 2002.p.35

MINISTÉRIO DO MEIO AMBIENTE, Fórum permanente desenvolvimento sustentável do Brasil - memória da reunião de instalação. Brasília, 2002.

MONNET, Jérôme. Revista do Patrimônio Histórico e Artístico Nacional.

Prudente, Leonardo. Informativo do Gabinete do Deputado Distrital Leonardo Prudente, Ano 01, No 03 - Julho/Setembro 2003.

SWARBROOKE, Jonh. Turismo sustentável - meio ambiente e economia. 2 ed.São Paulo. Aleph, 2000.

Secretaria de Cultura e Esporte - Departamento de Patrimônio Histórico e Artístico do Distrito Federal. A construção da cidade. Brasília. Oficina de Programação Visual da SCE, 1998. p.21-23

TRIGO, Luiz Gonzaga Godoi. Viagem na memória - Guia histórico das viagens e do turismo no Brasil. 2. ed. São Paulo: SENAC, 2000.

YÁZIGI, Turismo - uma esperança condicional. 2 ed. São Paulo, 1999 


\section{Documentos Orais}

Entrevista com o Sr. Marcos Pompeu de Souza Brasil, Secretário Adjunto do Governo do Distrito Federal e Secretário Executivo do Fórum Brasileiro de Secretários de Turismo

Entrevista com o Sr. Evander Wilson Marques, Coordenador de Esporte da AABB Associação Atlética Banco do Brasil 


\section{REFERÊNCIAS BIBLIOGRÁFICAS}

ANDRADE, José Vicente de. Turismo: fundamentos e dimensões. 8. ed. São Paulo: Ática, 2000. p.104

ANDRADE, José Vicente de. Lazer: princípios, tipos e formas na vida e no trabalho. Belo Horizonte: Autêntica, 2001 p.67-68 , 127-129.

Brasil. Projeto-Lei n 2924, de 20 de março de 2002. Dispõe sobre a criação do gerenciamento costeiro do Lago Paranoá.

Convention Bureau. Disponível na Internet em: $<\underline{w w w}$.brasiliaconvention.com.br $>$. Acesso em 14 out 2003.

FONSECA, Fernando Oliveira. Olhares sobre o Lago Paranoá. Gráfica Prática. Brasília, 2001

Jornal da CAESB. Brasília,2003.

Mondin, Guido - A lenda do Lago.Brasília, 1985.

Terracap - Projeto Pontão do Lago Sul.

GOVERNO DO DISTRITO FEDERAL, Projeto Orla.

Puttkakamer, Wolf Jesco Von. Brasília sob o olhar de JESCO (UNESCO). Ed UCG/Fundação Assis Chateaubriand. Goiânia/Brasília, 2000.

Revista Excelência, Edição 30, julho/2003 